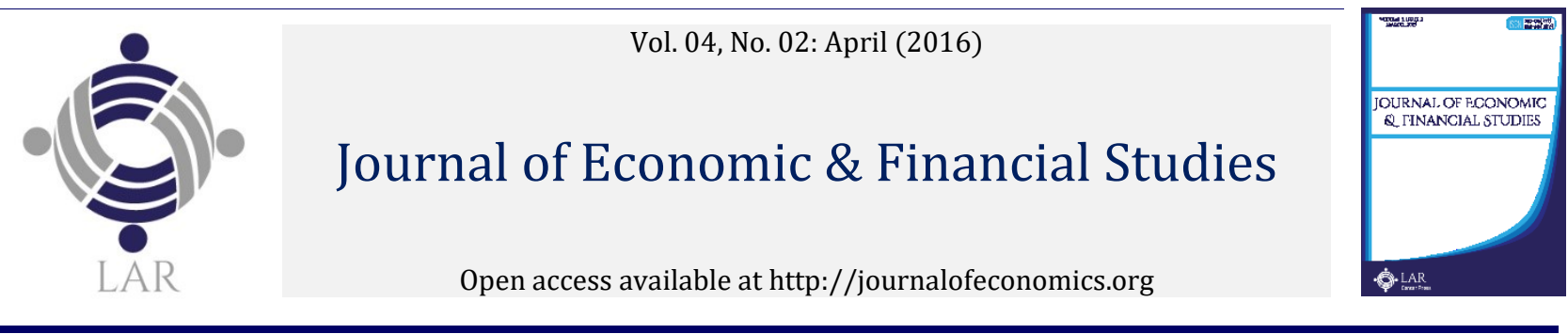

\title{
Still on board configuration: SEC recommendations and the efficiency of adhering firms in Nigeria
}

\author{
Bello Lawala* ${ }^{*}$ \\ a Glasgow Caledonian University, Scotland, United Kingdom \\ *Corresponding author's email address: lawal.bello@nlng.com
}

\section{A R T I C L E I N F 0}

Received: 16-02-2016

Accepted: 11-03-2016

Available online: 13-03-2016

Keywords:

Board structure;

Corporate governance;

Firm performance;

Macroeconomic variables.

JEL Classification:

G32; G34; G39.

\begin{abstract}
A B S T R A C T
This paper scrutinizes the effects of adherence to an encoded board configuration on firm efficiency in terms operational and financial performances using an integrated research framework that combines four distinct theories including agency, stewardship, stakeholders and resource dependency models. The research explores three main aspects of compliance outcomes; benefits accrued to conforming firms in terms of enhanced efficiency and market value, board level drivers as well as the external moderators of these benefits using a sample of 127 listed companies on the Nigerian Stock Exchange covering for the period of 19992010. Result show that board independence, directors' cognitive competencies as measured in terms of their educational qualifications and professional experiences are positively associated with efficient management of assets (ROA) and firm stock marketability (Tobin's q). I find no substantive empirical evidence to suggest that either the adoption of specific leadership structure or directors' ethnic representation affects firm performance. Moreover, country-level macroeconomic variables, especially the degree of economic openness play a significant role in determining the strength of association between board structure variables and firm performance measures.
\end{abstract}

(C) 2016 The Authors. This is an open access article under the terms of the Creative Commons Attribution License 4.0, which allows use, distribution and reproduction in any medium, provided the original work is properly cited.

DOI: http://dx.doi.org/ 10.18533/jefs.v4i02.215

\subsection{Introduction}

The spates of corporate scandals of the last twenty-five years had motivated significant drive towards institutional reforms particularly in numerous developed countries (e.g. Toshiba, Olympus, Enron, Lehman Brothers and WorldCom). One of the well cited examples of government response to these scandals is the passage into law of the famous Sarbanes-Oxley Act (2002) which is widely considered to be the most sweeping corporate governance regulation in the past 70 years (Bulent 2009). These waves of institutional reforms in the developed countries have motivated similar moves in the emerging markets. In Nigeria, where the quest for Direct Foreign Investments (FDIs) have heighten since the return to democratic governance in 1999, corporate governance has assumed a vital topic of public debate with significant focus on the internal mechanisms. The reason had been that comparable levels of corporate scandals were reported across key sectors. For instance, varying degrees of corporate malpractices led to the collapse of over fifty commercial banks between 1994 and 2011, whilst, an additional eight banks had to be rescued from impending bankruptcy (CBN 2011). The overstatement of the profit and balance sheets of Cadbury Nigeria Plc and the evidence of share price manipulation at the Fort Oil Plc (formerly African Petroleum) ensured that the two companies became the most famous cases of unethical practices in Nigeria (Egene 2009).

Regulatory responses to these corporate incidences were considerable as the institutional efforts saw the Nigeria Securities and Exchange Commission (SEC) issued the country's first ever Code of Corporate Governance in 2003 
(hereafter, SEC Code). In order to enhance board effectiveness, the SEC Code recommended board structure characteristics covering size, composition and leadership. However, there has been lingering debate regarding the relevance of these features to corporate efficiency in Nigeria. Questions have been asked as to whether these suggestions which had mirrored developed economies styles of corporate governance can lead to efficiency in the management of firms operating in the emerging economies with completely different socio-cultural disposition.

Attempts have been made to empirically examine how important these board features are in firm governance but findings from previous studies set in Nigeria have been equivocal (see: Uadiale 2010). The majority of these studies took an agency approach, focusing mainly on the issue of managerial self-interested behaviour at the expense of other board role fundamentals such as resource co-optation, harmonisation of stakeholders' interests and executive stewardship (e.g. Kajola 2008). Most of these studies also suffered from methodological inadequacies ranging from the use of weak model, assumption of definite relationship and absence of control and moderating variables amongst others (Lawal 2011).

Relying on the SEC Code recommendations with reference to appropriate board structure, this paper is aimed at addressing three key fundamentals questions which include; whether adherence to the SEC Code in terms of board configuration, predict firm performance in Nigeria? If such is the case, then which of the specific board features have significant influence on measures of performance? And finally, are there any other explanatory variables outside the board factors that significantly drive these performance variations?

It is interesting to note that, the influence of corporate governance on firm performance has been a subject of intense discussion for over twenty years, but mainly in the US, Europe and Latin America, and most recently in the Asian business context (Finegold et al. 2007). In Sub-Saharan Africa, particularly Nigeria, a review of the literature points to insufficient evidence as, so far, very little research has been conducted in this vital field (Elsayed 2011, Ongore and K'Obonyo 2011). This paper aims to add an African perspective to this important research stream. The choice of Nigeria as a case study was based on the fact that it housed one of the four largest stock markets in Africa and above all the largest economy in the Continent.

The current study was equally motivated by the desire to verify whether, in line with suggestions from some quarters, countries with relatively frail corporate regulations see statistically significant effects of corporate governance variables on firms' performance (see: Klapper and Love, 2004; Cadbury 2000). Compared with the progress made in other emerging countries, the Nigerian corporate regulations still lag behind due to significant developments not yet appropriately allowed for in the country's company laws (see: Quadri 2010).

Board diversity has been hypothesised to enhance firm performance (Anderson et al. 2011). Specifically, Cadbury (2000) identified the issues of directors' educational qualifications, experience and continuous development programmes as being prerequisites for directors' ability to add value to board deliberations. However, the majority of previous studies on board diversity have tended to focus more on demographic variables (e.g. Kang et al. 2007; Campbell and Mínguez-Vera 2008). Issues related to directors' cognitive competencies, has not received the desired attention as only few studies have so far been conducted in this area (see: Lückerath-Rovers 2011). This study attempts to fill these gaps and contribute to the growing literature on board diversity.

Finally, Tian and Lau (2001) argued that the external environment within which a firm operates is critical to the effectiveness of the internal governance mechanism. However, it is interesting to note that the mainstream of previous empirical studies have ignored this simple fact, even in developing economies where these environmental factors are of the utmost importance (Rwegasira 2000; Krambia-Kapardis and Psaros 2006; Klapper and Love, 2004). This study is thus motivated by the need to take into account the effects of macroeconomic fundamentals as mediator of the relationship between corporate governance and firm performance in the context of emerging markets.

The remainder of this paper is structured as follows: the second section deals with the review of relevant literatures and development hypotheses. Third section covers the description of research methodology. The fourth section was dedicated to analyses, discussion of results and theoretical as well as the practical implications of the empirical findings. The fifth section, which is the final part, focuses on the conclusion drawn and offered some directions for future research.

\subsection{Related literatures and hypotheses}

Corporate governance is said to involve a set of nexus between parties to the firm operations (see: OECD 2004:11). In practical terms, it encompasses every aspect of running a corporate entity, which amongst other things includes the deployment of both internal and external mechanisms. Of these instruments, the use of internal mechanisms represented by the board of directors stands out and thus well documented in governance literature. Corporate 
board often regarded as the most significant constituency, plays varieties of intermediary roles that link firms and their owners with those who provide professional management and other ancillary support services (see: Chen et al. 2009; Bozec, 2005). From the agency perspective, the role of board is symbolised by effective monitoring of the executive management team in a way that curtails the perceived moral hazard and residual risk associated with the separation of ownership and control (Weir et al. 2002). Unlike the agency theory, the stewardship theory explores the intrinsic value orientation of the executive management. As corporate stewards, they are seen as individuals who are motivated by non-financial gains such as achievement, growth, self-actualisation and acknowledgment. Here, the role of board, ceteris paribus, is more of strategy formulation and ratification since information asymmetry issues are said to be limited under stewardship notion (Ahunwan 2002).

Stakeholder theory took a rather broader view of corporations as societal entities with arrays of interested parties. As well as the immediate owners, whose funds are being placed at risk, stakeholders include other groups that are at the receiving end of whatever course of action the firm, through the board, decides to pursue (Pfeffer 1994). The roles of corporate board therefore, include balancing proportionately, interests between the numerous stakeholders. Adam and Shavit (2009) had however, stressed the need for distributive justice that gives preference to the shareholders' interests. In addition to harmonisation of divergence interests, boards are expected to play a "resource-picking "roles which includes scouting for vital information that give the firm a competitive edge over its peers (see: Markarian and Parbonetti 2007). Resource dependency theory was first captured in the work of Pfeffer and Salancik (1978) where they argued that a firm's power in terms of competitiveness is dependent on the amount of resources at its disposal, and that most of this wealth comes from the outside environment. Consistent with the dependency hypothesis, a corporation is seen as an entity whose success and survival hinge on the developments in the environment within which it operates. Corporations thus look to the environment for the sourcing of key resources including human resources, capital and raw materials (see: Pfeffer and Salancik 1978).

Interestingly, each of these board roles highlighted under the respective theories offered some form of implication for effective firm governance especially from board structure perspective. Berghe and Levrau (2004) suggested that an investigation of board structure should focus on four dimensions: size, composition, international presence, and cognitive capabilities and diversity. The present study adopted a rather modified version of these dimensions by focusing on the key board features (i.e. size, composition, CEO duality and diversity) that are consistent with the Nigerian SEC Code recommendations regarding board structure.

\subsection{Board size}

The size of the Board is regarded as one of the critical elements of board effectiveness and a key determinant of the quality of deliberations that goes on in the so-called black box (Goodstein et al. 1994). Issues of appropriate board size has been a subject of intense discussion with varying degrees of opinions shared when it comes to determining the size of directors that engenders board performance. (Yermack 1996). However, prior discussions have majorly focused on the debate between the relative benefits or otherwise of keeping large and small board membership (Guest 2009; Coles et al. 2008).

Apart from the perceived inherent risk of CEO dominance and entrenchment, proponents of large board size have relied on the availability of pool of knowledge, directors' independence and external network connections which enhance firms' access to mobilisation of critical resources and vital industry information as some of the key benefits derived from large Board size (Larmou and Vafeas 2010; Kang et al. 2007). Jackling and Johl (2009) noted that due to the high degree of heterogeneity among the members, large board sizes are backed by the presence of directors with in-depth cognitive capabilities that enhances the quality of board decisions. Coles et al. (2008) observed that large boards composed of a higher proportion of non-executives are more vigilant and effective in carrying out the board counselling role.

Critics who favoured small Board size have centred their arguments on the agency implication of such a structure. Yawson (2006) observed that excessively large board membership posed monitoring challenges and the tendency to become more vulnerable to managerial entrenchment. Small boards are more effective at monitoring the CEO, and are more likely to invoke appropriate discipline when necessary, especially in the face of a run of poor firm performance (Yermack 1996; Lipton and Lorsch 1992). Proponents of moderate board sizes have advanced the problem of boardroom coordination and communication gap due to over crowdedness as part of the constraints associated with large boards for which small boards enjoy a relatively comparative advantage (Muth and Donaldson 1998). Pacini et al. (2008) argued that group think-tank syndrome and potential conflict resulting from the emergence of splinter groups within boards are likely to reduce the effectiveness of large board sizes. Similarly, Hermalin and Weisbach (2003) established that as the size of the board grows, its tendency to move from being an active organ to a passive element becomes even greater. The issue of social loafing has also surfaced 
in a large portion of the literature as a negative consequence of a relatively large board size. Bozec (2005) noted that there is a tendency for certain members to act as box tickers and not necessarily contributing anything of value to board discourse.

Several studies have been conducted to determine the empirical validity of the idea of an optimal board size and its effects on firm performance and market value. Significant numbers of these studies have yielded inconsistent outcomes ranging from positive findings (e.g. Tanna et al. 2011) to negative results (e.g. Bennedsen et al. 2008; Mak and Kusnadi 2005). However, unlike other board characteristics, significant numbers of previous studies on board size overwhelmingly pointed to a negative relationship with firm performance measures (Guest 2009). Consistent with the pattern of these previous empirical outcomes, this study hypothesises that;

H1: Board size, irrespective of the measurement technique used is negatively associated with firm performance in Nigeria.

\subsection{Board independence}

Whenever it comes to gauging the level of board independence, the composition of directors is often used as a proxy (see: Chen et al. 2009). For the purpose of this study, board composition is defined in terms of the proportion of executives and non-executives directors who make up the board. Hermalin and Weisbach (1988) noted that the extent to which boards of directors are able to exercise legitimate power depends on their composition. Because insider directors are in possession of valuable corporate information and the nonexecutives bring to bear their expertise and objectivity, having an appropriate mixture of both categories of directors is strategic to firm governance (Byrd and Hickman 1992). Within the board composite however, the independent non-executive directors (NEDs) are seen as symbols of board freedom and sovereignty from CEO exuberant influences (Dalton et al. 1998).

The presence of these outside directors on corporate boards have been linked to different role plays, ranging from provision of independent judgement, expertise, resource co-optation and innovation, amongst others (John and Senbet 1998). Luan and Tang (2007) observed that NEDs are indication of good governance and strong external networks, which provide the management team with the strategic resources required to run the corporation successfully. Advocates of board independence have argued that, if the sole responsibility of the board of directors is to monitor the executives and the management team, then outside independent directors are more enthusiastic about instilling such control measures (Bhagat and Black 2000).

Despite the popularity that the case for increased non-executive representation has received, empirical evidence supporting claims that such an inclusion can engender improved firm value remains relatively unclear due mixed results that continued to dominate empirical findings (Finegold et al. 2007). In a study of panel data consisting of 672 UK listed firms, Mura (2007) found that the fraction of NEDs on a board was significantly and positively associated with market value. Positive results were equally reported in other similar empirical studies (e.g. Tanna et al. 2011; Shan and McIver 2011; Perry and Shivdasani 2005). However, Randøy and Jenssen (2004) conducted an empirical investigation into a selected number of firms facing strict product market competition and found that board independence was counterproductive to performance. Similarly, Bhagat and Black (2000) investigated the long-term effect of board independence using a sample of 934 largest US public companies and found no evidence to suggest that firms benefit financially from such an inclusion.

Conclusively, while the current study recognises the equivocality of previous empirical findings regarding the strategic relevance of independent NEDs (see: Jackling and Johl 2009; Kim 2007), the assumption that the presence of these outside directors enhances board monitoring and vigilance remains popular. Consistent with the above and the fact that the SEC Code had offered similar recommendations in Part b(4.3) that "...the majority of Board members should be non-executive directors, at least one of whom should be independent director", this study hypothesises as follows:

H2: There is a statistically significant positive relationship between the presence of independent nonexecutive directors and firm performance in Nigeria, irrespective of the scenario and performance measures used.

\subsection{CEO duality}

Debate on the dual leadership structure is centred on whether the CEO should be allowed to hold the two top leadership positions within a corporation. Though many codes of corporate governance are structured in favour of the agency theory orientation, which encourages separation of power, advocates of CEO duality have emphasised the need for unity of command and control at the top management level (Dahya and Travlos 2000). 
Proponents of duality have observed that the creation of the board chair position is more a conventional wisdom, which may not necessarily be effective in the actual governance of firms. Therefore, harmonisation of the positions, with the CEO at the helm, creates purposeful and clearly focused corporate leadership. Elsayed (2007) argued that the approach eliminates ambiguities and decreases the role conflicts that are usually associated with the separation of decision management and control functions. This enhances firm efficiency particularly the speed of corporate decision making (Boyd 1995).

The need for separation of power through non-duality has remained the most dominant school of thought. The reason for this shared sentiment is not farfetched. Series of reported corporate scandals have all pointed to the failure of leadership, especially the overbearing influence of CEOs on the Board of Directors (Jackling and Johl 2009). Therefore, a dual leadership structure in which corporate authority resides with the CEO is adjudged to be detrimental to shareholders' protection (Laing and Weir 1999).

Public debates have thus favoured an independent leadership structure that ensures decentralisation of power at the top corporate level. The situation in Nigeria's corporate environment is no exception to this bias. Critics have suggested that combining the two positions would impair objectivity and induced conflict of interest, as this could amount to being an arbitrator in one's own defence (Wan and Ong 2005). CEOs are said to be unable, by virtue of their position in the management team, to offer the kind of unbiased leadership that is required under contemporary institutional arrangements (Arslan et al. 2010). Laing and Weir (1999) argued that having too much power concentrated in the hands of an individual is likely to increase potential agency costs since it provides little or no room for checks and balances. This, according to Boyd (1995), will subdue board's usefulness in discharging its fiduciary obligations. Rechner and Dalton (1991) asserted that the quest for corporate probity, transparency and accountability might be compromised because of CEOs' overbearing tendencies resulting from the high concentration of power. In principle, the roles expected of the executives and the board of directors creates two separate constituents with very distinct functions. Therefore, handing so much power over these two different constituents to one person may amount to an aberration.

Ironically, the issue of corporate leadership structure has not commanded the same level of popularity and attention - in terms of volume of empirical evidence - as other board dynamics, such as size and composition (see: Rechner and Dalton 1991). Results from the few available studies are almost inconclusive as mixed evidences have been reported regarding how CEO duality impact firm performance (see: Elsayed 2007). In a study of 192 US firms drawn from twelve different industries, Boyd (1995) found CEO duality to be both positively and negatively associated with firm performance, depending on the prevailing environmental conditions facing the firm, mainly generosity, dynamism and complexity. Elsayed (2007) reported that the effect of CEO duality on firm performance varied significantly across industrial groupings and that both the agency and stewardship theories are crucial to understanding the association between the two variables (Elsayed 2007).

Despite not being absolutely supported empirically, the call for a separation of power has received tremendous citations (Faleye 2007). The Nigerian SEC Code had equally offered similar endorsement encouraging CEO nonduality. Consequently, this study adopted the following hypothesis:

H3: There is a statistically significant negative link between the adoption of a dual CEO leadership structure and the performance of listed firms in Nigeria.

\subsection{Board diversity}

Globalisation has increasingly changed the dynamics of firm composition in terms of workforce. People of different diverse demographic and cognitive backgrounds are being co-opted into working together to achieve a common goal (see: Gomez-Mejia et al. 2005). At the board level, diversity entails having a board composition of directors not only from different cultural, ethnic, national, and other racial divides, but also of competent, qualified and experienced individuals from diverse background who bring to bear their versatility and external connections. Board diversity can be subdivided into demographic and cognitive characteristics. While board demographic features are easily recognisable, the cognitive characteristics are not obvious. To this end, significant numbers of previous studies have placed greater emphasis on demographic components such as gender, age, race, nationality and ethnicity because of its perceived empirical simplicity (Lückerath-Rovers 2011; Hagendorff and Keasey 2010; Campbell and Mínguez-Vera 2008). Only very few studies on board diversity can be found on cognitive-related issues such as directors' educational qualifications, professional memberships, industry experience and external network density (see: Anderson et al. 2011).

Early debates on the importance of board diversity are concerned with whether the directors' gender diversity; specifically the presence of female directors enhances the effectiveness of corporate boards. This aspect has resulted in two lines of arguments i.e. the corporate fair play built on "equality" and value maximisation which 
represents the "business case" for board diversity (see: Carter et al. 2003). Anchored in the stakeholder theory, advocates of corporate fairness argue in favour of the need to involve people of different races, sexes and cultures in the management and running of corporations, especially at the top level (Hagendorff and Keasey 2010). Regarding the business case, board diversity issues are entrenched in both the agency and resource dependency theories of corporate governance. Boards of directors composed of individuals from diverse demographic and cognitive backgrounds are seen as corporate assets whose synergistic effects are linked to increased firm performance (Hagendorff and Keasey 2010). Gender equality advocates have thus argued that women with excellent cognitive abilities need not be discriminated against, as they are just as capable of contributing meaningfully to board deliberations as their male counterparts (Carter et al. 2010). Kang et al. (2007) observed that female directors are much more independent as they are usually detached from the "old boys" syndrome, which allows them to offer an unbiased perspective during board meetings.

Interestingly, a new paradigm shift has emerged in the board diversity debate, with more focus on directors' cognitive characteristics, an aspect which had been under-studied in the past (see: Darmadi 2013). Issues related to academic qualifications have received most of the interest with predominant empirical works focusing on the effects of the directors' level of education on firm performance. Kim and Lim (2010) found that directors' fulfilment of their advisory role increases when they possess certain academic qualifications, especially in the areas of business and law. Advocates of cognitive board diversity strongly believe that the effectiveness of corporate board lies in the directors' aggregate competencies, which shape the quality of deliberation that goes on inside the boardroom. According to Lückerath-Rovers (2011) the cognitive heterogeneity among board members facilitates access to vital industry information that guides corporate strategic decisions. As a firm evolves from a single-country operator into a global player, understanding the unique characteristics of each market segment becomes more important for corporate strategic planning and firm competitiveness. Therefore, the composition of the board of directors that will ultimately make corporate strategy decisions needs to reflect the diversity in the marketplace. Eklund et al. (2009) noted that these diverse board memberships enhance a firm's ability to comprehend and keep track of changes in the external environment. Walt and Ingley (2003) argued that directors' cognitive characteristics are social capital that firms with a diversified board composition can tap into. The presence of well-connected directors, which usually accompanies diversity in the boardroom, makes it easier for firms to raise funds and attract other critical resources from the public. Nordberg (2011) contended that these included not only access to cheap capital, but also favourable regulatory treatment.

Remarkably, whereas, research evidence supporting demographic diversity remained inconclusive, findings from those that had investigated the effect of cognitive diversity were somewhat aligned (Nielsen and Huse, 2010; Randøy et al. 2006; Carter et al. 2003). Darmadi (2013) in a study consisting of 160 firms listed on the Indonesian Stock Exchange found that the directors' educational qualifications were instrumental to firm's improved performance. Fairchild and $\mathrm{Li}$ (2005) examined hostile takeovers as a predictor of directors' quality and reported that the quality of the board of directors, as measured in terms of their wealth creation propensity, played a crucial role, not only in the firm's governance, but in its continued existence as a going concern. These evidences were further affirmed by other similar research outcomes (e.g. Hsu 2010; Bhagat et al. 2010; Jalbert et al. 2002).

In line with the above empirical trends and the fact that the Nigerian SEC Code had in Part b(4.1) emphasised that the Board "should be composed in such a way as to ensure diversity of experience without compromising independence, compatibility, integrity and availability of members to attend meetings", this study adopted the following hypotheses:

H4: The presence of directors with MBA is significantly associated with improved performance among companies quoted on the Nigerian Stock Exchange.

H5: There is a statistically significant positive relationship between directors' experience and the performance of companies quoted on the Nigerian Stock Exchange.

H6: The proportion of directors on a board that come from the three major ethnic groups is negatively associated with improved firm performance in Nigeria.

\subsection{Methodology and model specification}

\subsection{Conceptual framework}

Previous studies on the effect of board structure on firm performance has been characterised by inconsistent findings because of faulty research framework (see: Lawal 2011). The majority of these empirical studies had adopted the direct relationship approach whereby firm performance proxies are regressed against the relevant board variables of interest (e.g. Guest 2009; Yermack 1996). Various recommendations have been offered with respect to ways of addressing previous methodological flaws while simultaneously bringing robustness to future 
studies. Some of the new approaches suggested include the use of multiple theories, the deployment of multidimensional performance measures, and the inclusion of external environmental factors such as macroeconomic, societal and regulatory variables (see: Şener et al. 2011; El Sood 2008; Finegold et al. 2007; Nicholson and Kiel 2007; Ugur and Ararat 2006; Muth and Donaldson 1998).

Consistent with these suggestions, this study adopted an integrated approach and thus extended the constructs of the traditional econometric model commonly used in corporate governance studies from its simplistic form to one that includes variables capturing external environmental forces specifically the macroeconomic factors (see: Ugur and Ararat 2006). The underlying premise upon which this study was built is that firm performance in Nigeria is a function of adherence to SEC Code's recommended board structure and the overall macroeconomic situation facing the country at any given point. The sophistication of this framework is evident in the hypothesis advanced by Ugur and Ararat (2006) in support of an empirical shift towards the extended model in the study of the relationship between corporate governance and firm performance. They argued that past studies have ignored the effect of macroeconomic stability on firm performance. While good corporate governance might have the potential to improve a firm's performance, the presence of macroeconomic stability, or the lack of it, can equally promote or hinder performance (Ugur and Ararat 2006). They further contended that, in the hierarchy of determinants of firm performance, the first element in the pecking order is the rate of return, a variable linked to the macroeconomic factor. Consistent with previous investigations, the current study adopts two variables, the level of economic growth and the degree of economic openness, as proxies reflecting the general macroeconomic situation in Nigeria (see: Wanyama et al. 2009; El Sood 2008; Naceur et al. 2007; D’Souza et al. 2005; Boubakri et al. 2005).

Figure 1: Conceptual framework of corporate governance and influence of macroeconomic variables on the performance of firms in Nigeria

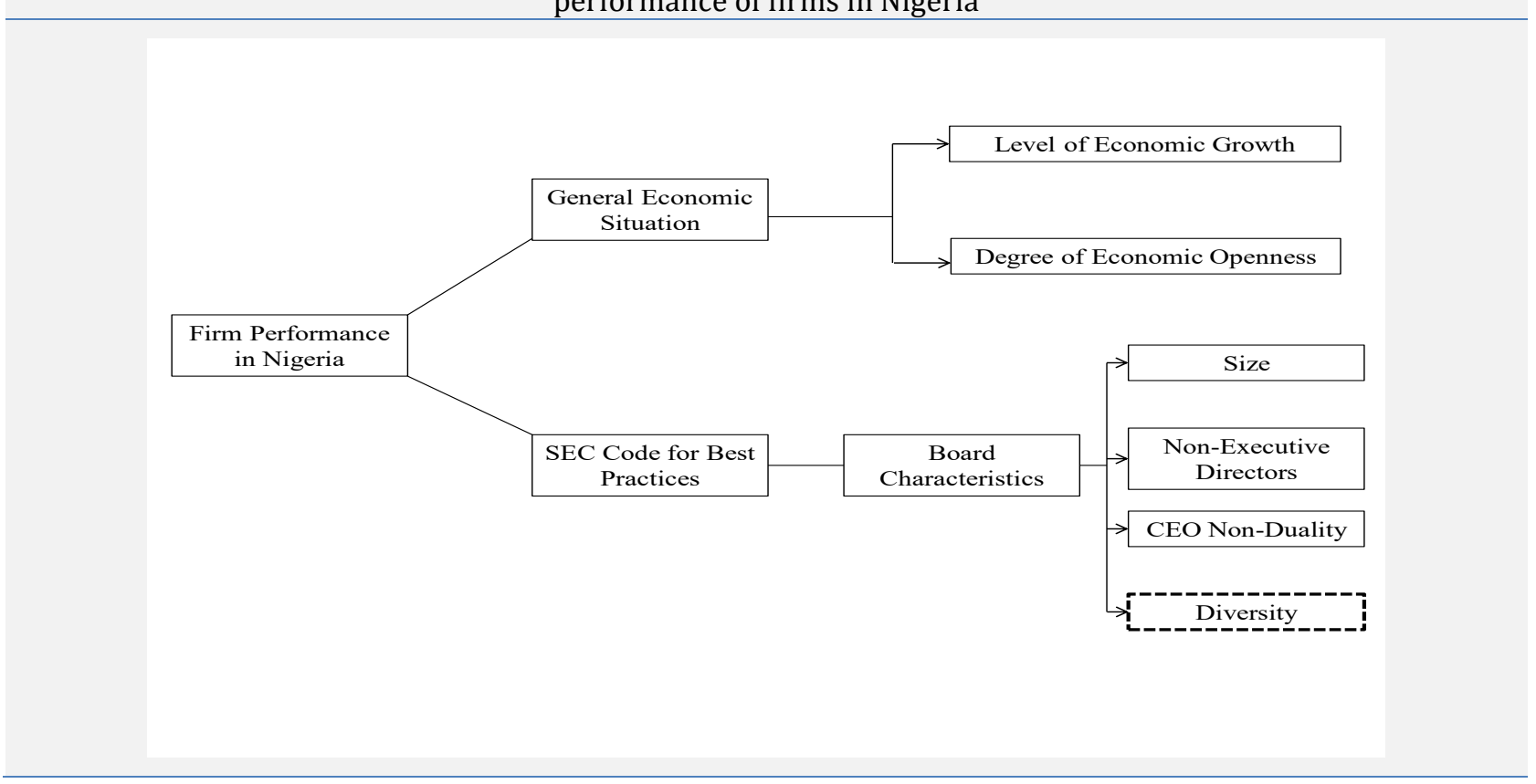

\subsection{Data and sample determination}

This study is based on panel data from 177 firms listed on the Main Board of the NSE between $1^{\text {st }}$ January 1999 and 31 ${ }^{\text {st }}$ December 2010. Qualitative data in respect of board characteristics were collected from the Nigerian SEC Database and the respective companies' annual reports. Macroeconomic data related to economic growth and the levels of economic openness were extracted from the 2011 CBN Annual Bulletin. Information on financial performance was composed from the respective companies' annual reports and the Nigeria Stock Exchange (NSE) Fact Books. Information on share prices for all of the companies considered were collected from the NSE Daily Price List, specifically on the last trading day of each of the financial years.

In order arrived at final sample that is reflective of the entire population and reduce the problematic nature of an unequal data sample, a filtering mechanism was developed. For a firm to be included in the final sample, therefore they had to be a listed company whose shares were traded on the floor of the NSE uninterruptedly for at least the twelve-year period between 1999 and 2010. The second consideration is the availability of audited annual financial reports for the period under consideration and finally the accessibility of detailed information on corporate governance disclosure, especially on the structure of the board of directors for 2003/2004 and 
2009/2010 financial years. Whilst 2003/2004 represents the era prior to the introduction of SEC Code, the 2009/2010 financial year represents the post-2003 SEC Code era and the emergence of the 2009 reversed code.

Using the above parameters, the total number of eligible companies decreased from 177 to 127 , and these companies formed the final sample size used throughout the various stages of the empirical analysis. The composite of firms that made final sample represents 72 per cent of the total number of quoted companies that had traded on the NSE platform as at the end of the 2010 financial year. The combined market capitalisation of these firms covers approximately 90 per cent of the market's all-share index. It is important to equally note that the final data sample used in this study is still the largest sample size ever used, so far, in a single empirical study in the context of Nigeria (e.g. Kajola 2008; Udiale 2010).

\subsection{Definition and estimation of variables}

The study adopted two sets of performance measures i.e. the accounting and market value-based techniques. Meyer (2002) noted that these measures focus on both the historical performance and future expectations. Tobin's $q$, a measurement of firm market value, provides the basis for statistical inferences regarding the investors' appetite for the firm's stock, whilst the use of accounting-based measures - return-on-assets (ROA) and net profit margin (NPM) enables the study to draw conclusions regarding the operational efficiency and profitability (see: Gentry and Shen 2010). Tobin's $q$ is defined as the ratio of market capitalisation plus the book value of debt, to the total assets (e.g. Mak and Kusnadi 2005). ROA is taken as the ratio of net profit to total assets or net worth (see: Bennedsen et al. 2008). NPM, as a profitability ratio, is crucial to ascertaining the relative internal strength of a firm and the degree to which it can survive in turbulent times as a going concern. In this study, NPM is defined as the ratio of turnover to net profit. This definition is consistent with approaches adopted in Raithatha and Bapat (2012) and Gill et al. (2008).

Board size (BS) is used in this study as an independent variable and estimated in the model as the total number of directors on the board (e.g. Pacini et al. 2008; Yermack 1996). The definition of board independence (BI) offered in this study is an adaptation of the SEC Code's definition and it is taken as the proportion of independent NEDs, who are not current or former employees of the company and whose stake in the company is less than 0.1 per cent. Board independence is captured in the model as the total number of independent NEDs on the board during the relevant financial years (e.g. Mura 2007; Peng 2004; Weir et al. 2002). CEO duality (CEODUAL) is captured as a dummy variable and coded in binary which takes the value one (1) if CEO doubled as the Board Chair, signifying a dependent leadership structure and the value, zero $(\sigma)$ if the positions are separate suggesting an independent leadership configuration (e.g. Elsayed 2011; Chen et al. 2009). Board cognitive diversity, as employed in this study, is captured using two different proxies; the number of directors who hold MBA (DMBA) and the directors' average years of work experience-AVGEXP (e.g. Anderson et al. 2011; Hsu 2010). The demographic diversity is captured using ethnicity proxy and measured in two ways. The first approach measured board ethnic diversity (ER) on the basis of the absolute number of directors from the three major ethnic groups in Nigeria (i.e. Hausa, Yoruba and Igbo). The second approach uses the Blau index, a measure of heterogeneity and equilibrium: $1-\sum^{\mathrm{n}} p_{i}^{2}$ where $\mathrm{p}$ is the proportion of directors from major ethnic groups (see: Darmadi 2013).

Relying on Ugur and Ararat's (2006) line of thought, as highlighted in the preceding section, two external variables that reflected Nigeria's macroeconomic situation are employed namely; the level of economic growth and degree of economic openness. The level of economic growth (LOGGDP) is defined as the rate of change in the real GDP year-on-year, while the degree of economic openness (LOGOPENNESS) is captured as the ratio of the balance of trade to GDP. Both definitions are consistent with methodologies used in previous studies (e.g. El Sood 2008; Nacuer et al. 2007; D'Souza et al. 2005).

\subsection{Control variables}

In the field of management sciences, endogeneity effect, resulting from simultaneity, omitted variables, measurement errors and other model specification errors has been identified as key impediment to reliability and robustness of empirical outcomes (see: Chenhall and Moers 2007). Most of the reported inconsistencies in the corporate governance research findings are thought to be linked to the inability of previous researchers to control the endogeneity effects in the estimated models (Wintoki, Linck, and Netter 2012). Bhagat and Black (2000) observed that the use of control variables can mitigate these potential errors and biases, thereby enhancing the credibility of statistical results. The study thus adapted two sets of control variables to moderate the potential effects of endogeneity on the proposed models. Firm Leverage (LEV) is introduced as a control variable and measured as the ratio of debt to assets (see: Chen et al. 2009; Pacini et al. 2008). The second control variable is Firm Size (FS) and it is measured as the logarithm of turnover (e.g. Yammeesri and Herath 2010; Nicholson and Kiel 2007). 


\subsection{Diagnostic tests and model specification}

\section{Pre-diagnostic tests}

In order to ensure a fair and balance evaluation throughout the empirical process, a series of preliminary tests were conducted on the data sets and variables to be used in the regression model, to ascertain their reliability, level of usefulness and predictive power. Chow breakpoint test was conducted on pre- and post-SEC-Code board structure and the CUSUM (cumulative sum of squares residual) test was further carried out to validate the sustainability of the Chow breakpoint results. Both the board structure and the macroeconomic variables were subjected to Stationarity (Unit Root) and the Normality tests to ascertain the degree of data spread and the normality of data distribution. These preliminary assessments were consistent with the empirical works of AlHaddad et al. (2011) and that of Lam and Lee (2008).

\section{Model specification}

The relationship between performance measures and the SEC Recommended board characteristics is tested using two clusters of multivariate regression models with each Cluster consisted of a base and sensitivity models. The first cluster, in equations (1) and (2) below, represents an intermediate analysis, designed to answer the first two of the three research questions. Using the base model, Tobin's $q$, a measure of firm performance (FP) was regressed against the board structure variables. Further sensitivity analyses are then conducted on the results from the base model, using equation (2) with net profit margin (NPM) as a proxy for FP. Sensitivity analyse was designed to evaluate the degree to which the base model results are sensitive to the performance measure (see: Darmadi 2013).

$$
\begin{aligned}
& \text { Cluster 1: Intermediate Multivariate Analysis } \\
& \text { Base Model } \\
& \mathrm{FP}_{\mathrm{it}}=\alpha_{1}+\beta_{1} \mathrm{BS}_{\mathrm{it}}+\beta_{2} \mathrm{BI}_{\mathrm{it}}+\beta_{3} \mathrm{CEODUAL}_{\mathrm{it}}+\beta_{4} \mathrm{DMBA}_{\mathrm{it}}+\beta_{5 \mathrm{~A}} \mathrm{AVGEXP}_{\mathrm{it}}+\beta_{6} \mathrm{ER}_{\mathrm{it}}+\beta_{7} \mathrm{LEV}_{\mathrm{it}}+\varepsilon_{\mathrm{it}} \\
& \text { Sensitivity Model } \\
& \mathrm{FP}_{\mathrm{it}}=\alpha_{1}+\beta_{1} \mathrm{BS}_{\mathrm{it}}+\beta_{2} \mathrm{BI}_{\mathrm{it}}+\beta_{3} \mathrm{CEODUAL}_{\mathrm{it}}+\beta_{4} \mathrm{DMBA}_{\mathrm{it}}+\beta_{5 \mathrm{~A} A V G E X P_{i t}}+\beta_{6} \mathrm{ER}_{\mathrm{it}}+\beta_{7} \mathrm{LEV}_{\mathrm{it}}+\varepsilon_{\mathrm{it}}
\end{aligned}
$$

The second cluster models combine the features of Cluster 1 as well as the inclusion of external moderators (i.e. level of economic growth and degree of economic openness). Cluster 2 models were designed to affirm the robustness of Cluster 1 findings and offered empirical response to the final of the three fundamental questions that were raised at the beginning of the study. Equation (3) represents the base model and Tobin's $q$ is regressed against the board and macroeconomic variables, with the outcome further exposed to a sensitivity test using ROA equation (4). The adopted models in this cluster are consistent with the previous empirical studies (e.g. El Sood 2008; Bozec 2005; D'Souza et al. 2005).

\section{Cluster 2: Extended Multivariate Analysis}

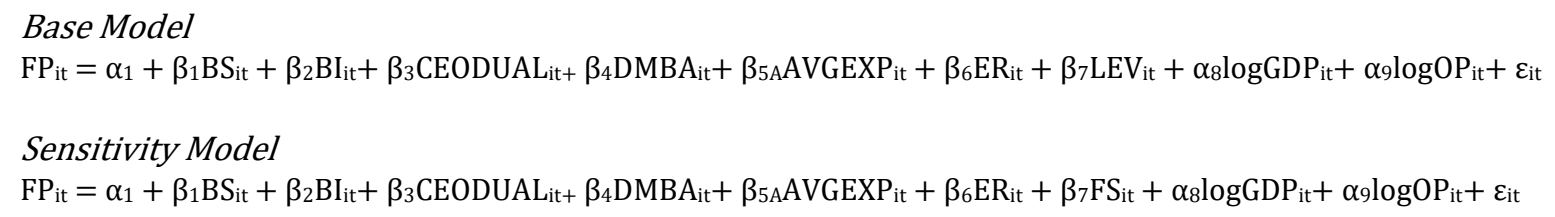

\section{Post-diagnostic tests}

This study is designed, not only to investigate the variables that determine firm performance in Nigeria, as has been the case in most of the previous studies, but to likewise ascertain the relevance of these drivers of performance in the long run. Two sets of post-diagnostic examinations are conducted on the regression models using the augmented Dickey-Fuller (ADF) co-integration and Theil inequality coefficient forecast tests. The cointegration test covers every aspect of the entire model, both deterministic and non-deterministic variables. This extensiveness facilitates the spotting of any potential spuriousness in the regression results that were obtained across the two clusters (see: Marmol and Velasco 2004). The co-integration test was introduced to serves as a robustness check regarding the long-term sustainability of the model in explaining the causality between the board characteristics and performance measures as moderated by the macroeconomic variables. Interestingly, this approach was equally consistent with those adopted in previous studies (e.g. Rogers et al. 2008). The second post-diagnostic analysis, the Theil inequality coefficient forecast test was conducted to determine the reliability and predictive accuracy of the models across the three multidimensional performance measures (i.e. ROA, NPM 
and Tobin's q). The application of the Theil inequality coefficient is appropriate following the regression analysis to compare how far the actual model results are from the forecast. The coefficient is sub-divided into three measures: bias, variance and covariance. Whilst the forecast test is conducted for the three measures, statistical inferences regarding the precision and otherwise of the models is drawn using Theil's outcome of bias component, which measures the systematic error in the forecast model (see: Ocram and Biekpe 2007).

\subsection{Empirical results and discussions}

\subsection{Description statistics}

As highlighted in the preceding section, Nigeria operates a unitary board system, typical of most Anglo-Saxon countries. The board of directors comprises both executives and NEDs. The table 1 below shows the descriptive statistics of the board characteristics for the sample of firms covered in this study. An average board size (BS) in Nigeria, is approximately ten, which is above the minimum of five specified in the SEC Code. It is likewise within the band recommended in some previous empirical studies (e.g. Lipton and Lorsch 1992). Board independence (BI), which measures the monitoring role played by the corporate board, shows an average of three NEDs, representing almost 30 per cent of the average board size of the firms in the sample. This implies adequate representation of outside independent directors who held less than 0.1 per cent of the shares. The SEC Code had recommended the presence of at least one of such independent director on the boards of listed firms. Therefore, it might not be out of place to conclude that the board monitoring role is crucial to shareholders in Nigeria.

\begin{tabular}{|c|c|c|c|c|c|c|c|c|}
\hline \multicolumn{9}{|c|}{ Table 1: Descriptive of statistics of board structure and performance measures } \\
\hline Variables & BS & AVGEXP & $\mathrm{BI}$ & DMBA & ER & ROA & Tobin's q & NPM \\
\hline Minimum & 5 & 5.38 & 0.00 & 1.00 & 2.00 & $-2.15 \mathrm{E} 4$ & -150.27 & -3144 \\
\hline Maximum & 20 & 40.4 & 9.00 & 9.00 & 20.00 & 3206.96 & 1206.22 & 373.13 \\
\hline Mean & 9.57 & 20.32 & 2.78 & 2.57 & 7.78 & -4.23 & 8.97 & -1.77 \\
\hline Std. Deviation & 3.07 & 7.37 & 1.81 & 1.71 & 3.54 & $1.2 \mathrm{E} 3$ & $7.1 \mathrm{E} 1$ & $2.2 \mathrm{E} 2$ \\
\hline
\end{tabular}

The majority of companies in Nigeria have fully complied with the SEC recommendation regarding the separation of power at the top corporate level. Approximately 98 per cent of the companies covered in this study have adopted clear CEO non-duality with the positions of board chair and CEO occupied by two different individuals (see: Appendix 1). The directors in the study sample have an average of twenty years' experience, and a minimum of five years. At least three board members hold MBA, a cognitive qualification necessary for strategic business policy decision making (see: Hsu 2010; Bhagat et al. 2010). On average, eight directors on the boards of quoted companies in Nigeria are drawn from within the three major ethnic groups, namely Hausa/Fulani, Yoruba and Igbo.

Regarding the firm performance measures, the two accounting-based techniques, ROA and NPM, have negative average ratios of -4.23 and -1.77 . These descriptive results imply that an average firm in the sample experienced negative financial performance over the period being investigated with regards to the management's efficiency at utilising the firms' assets and execution of marketing and distribution strategies. On the market value technique that measures the marketability of the firm in terms of investors' sentiment towards the company's stock, the Tobin's $q$ is positive, with an average of 8.97 for the sample of 127 firms investigated.

\subsection{Results of pre-diagnostic tests}

Chow breakpoint test was conducted on the pre- and post-SEC-Code board structure data. The p-value of the Ftest showed that the F-statistic (0.424) was not statistically significant at the 5 per cent level (see: Appendix 2). As a result, the null hypothesis that $\mathrm{H}_{0}: \mu_{1}=\mu_{2}$ was not rejected. Consequently, this study accepts that there is no significant difference in board structure between the periods before and after the SEC Code's introduction, in the sample of listed companies investigated. This result is confirmed by the results of the CUSUM test on the breakpoint (shock), taken to be the 2004 financial year when the SEC Code became effective. The CUSUM graph shows that the trend stays within the acceptance region, which implies that the non-significant nature of the Chow breakpoint test result is sustainable over a long period (see: Appendix 3). Given the above result, the study is at liberty to use any of the partitioned data. Hence, the decision was made to adopt the post-Code data across the entire analysis (i.e. board structure data for the 2010 financial year). This approach is consistent with the methodology adopted in Tian and Lau, (2001), where the 1996 financial year was taken as the base year and some other similar studies (see: Chen et al. 2009).

The normality test found the spread to be normally distributed around a zero mean and constant variance, except for the directors' average number of years of experience (AVGexp) (see: Appendix 4). This result shows that the data collected for the purpose of this study are well spread and cut across the entire population under 
investigation. The implication is that the outcome derived from this empirical investigation is most likely to be free from the inherent heteroskedasticity problem often associated with non-randomly distributed data. When data are normally distributed, it is easier to observe statistically the degree of spread within the sample. The absence of abnormality in data usually leads to more credible regression results and better statistical inferences (see: Razali and Wah 2011).

Granger (1969) observed that the use of non-stationary variables can lead to spurious regression results. Therefore, both the dependent and independent variables used in this study were further subjected to stationarity tests, as described in the previous section (using Levin, Lin and Chu; Pesaran and Shin; ADF-Fisher chi-square; Philip, Peron and Fisher chi-square). The stationarity test results show that the country-level macroeconomic variables (i.e. level of economic growth and degree of economic openness) and one of the accounting measures of firm performance (NPM) are stationary at the first difference. The proxies for board structure (i.e. board size, board independence, board experience, CEO duality, board professional qualifications and ethnic representation) and the control variables (i.e. leverage and firm size) are stationary at level (see: Appendix 5). The stationarity results validate the stability of the variables of interest used in the model, implying that the variables show no seasonality-driven behaviour but are rather stable over time.

\subsection{Results of the regressions}

Consistent with the proposed research methodology for the cluster one, performance measure was regressed against board variables without the inclusion of the macroeconomic variables (see: Table 2). The explanatory power of the resulting base model was high, with an $\mathrm{R}^{2}$ of 0.645 , which signifies that the model explains over 60 per cent of the variations in firm performance as measured by Tobin's $q$. The results of the base model regression show that the directors' years of experience (AVGEXP) and board independence (BI) are positive and significantly associated with Tobin's $q$ a measure of market value at the 5 per cent level. Board size (BS), CEO duality (CEODUAL), directors' educational qualifications (DMBA) and ethnic representation were also positively related to the performance measure but statistically insignificant.

\begin{tabular}{|c|c|c|}
\hline \multicolumn{3}{|c|}{ Table 2: Board features as determinants of firm performance } \\
\hline \multirow{2}{*}{ Variable } & Base Model (1 obin s q) & Sensitivity Model (NPM) \\
\hline & OLS Result & OLS Result \\
\hline \multirow[t]{2}{*}{ Constant } & 0.009 & -0.006 \\
\hline & $(0.144)$ & $(-0.104)$ \\
\hline \multirow[t]{2}{*}{ BS } & 0.077 & 0.076 \\
\hline & $(0.728)$ & $(0.728)$ \\
\hline \multirow[t]{2}{*}{ AVGEXP } & $0.129^{a}$ & $-0.148^{a}$ \\
\hline & $(1.863)$ & $(-2.139)$ \\
\hline \multirow[t]{2}{*}{$\mathrm{BI}$} & $0.089^{a}$ & $-0.088^{a}$ \\
\hline & $(1.244)$ & $(-1.243)$ \\
\hline \multirow[t]{2}{*}{ CEODUAL } & 0.036 & -0.034 \\
\hline & $(0.582)$ & $(-0.556)$ \\
\hline \multirow[t]{2}{*}{ DMBA } & 0.042 & -0.053 \\
\hline & $(0.623)$ & $(-0.788)$ \\
\hline \multirow[t]{2}{*}{ ER } & 0.000 & -0.003 \\
\hline & $(0.003)$ & $(-0.036)$ \\
\hline \multirow[t]{2}{*}{ LEV } & $0.081^{b}$ & $-0.080^{a}$ \\
\hline & (1.214) & $(-1.215)$ \\
\hline $\mathrm{R}^{2}$ & 0.645 & 0.644 \\
\hline Adjusted $\mathrm{R}^{2}$ & 0.541 & 0.562 \\
\hline$F$-statistics & 1.404 & 1.606 \\
\hline$P$-Value(F-statistics) & 0.00 & 0.00 \\
\hline \multicolumn{3}{|c|}{ Notes: a significant at 5\% level; b significant at 10\% level; $t$-statistics values captured in parentheses } \\
\hline \multicolumn{3}{|c|}{$\begin{array}{l}\text { ROA is measured as the ratio of net profit to a firm's total assets. NPM is measured as the proportion of sales to net profit. Tobin's } \\
\text { q is derived as the ratio of a firm's market capitalisation to total assets. Board size is estimated as the total number of directors on } \\
\text { the board. Board Independence is captured as the total number of independent NEDs on the board. CEO Duality is captured as a } \\
\text { dummy, which takes the value one if the same person holds the two positions and the value zero if the positions are separated. } \\
\text { DMBA is captured as the number of directors with an MBA. AVGEXP is captured as the average number of years of work experience } \\
\text { of the directors. ER is captured as the proportion of directors from the three major ethnic groups in Nigeria. Firm Leverage is } \\
\text { measured as the ratio of firm debt to assets. }\end{array}$} \\
\hline
\end{tabular}

A follow-up sensitivity test was conducted on the preceding base model results to verify the robustness of the outcomes discussed above. Consistent with the previous operational procedure, the macroeconomic variables were dropped. In addition, a different measure of performance, NPM, was introduced to replace Tobin's $q$. The idea was to test whether the results obtained were sensitive to the performance measure employed. The performance of the sensitivity model, especially in terms of its explanatory power, was consistent with the base 
model. The $\mathrm{R}^{2}$ and F-statistic of the model are 0.644 and 1.606 respectively. The p-value of 0.008 is much less than the 5 per cent $(<0.05)$ critical threshold, which indicates that the entire model is statistically significant.

In the sensitivity model, three variables - directors' years of experience (AVGexp), board independence (BI) and firm leverage (LEV) - remained statistically significant although they exhibited an inverse relationship with the firm performance proxy NPM. On the other hand, board size (BS), CEO duality (CEODUAL), directors' educational qualifications (DMBA) and ethnic representation (ER) were found to be statistically insignificant in this model. It is interesting to note here that, while some variables maintained the same level of statistical significance, the effect of their relationship with the dependent variable, NPM, changed from that in the base model, where Tobin's $q$ was used. For instance, the effect of board independence and directors' years of experience on firm performance, initially positive, became negative and statistically significant at the 5 per cent level. The proportion of directors with MBA and directors from major ethnic groups were found to be negatively and statistically insignificantly related to firm performance in this model. Board size was found to be positively associated with NPM but not statistically significant. While CEO duality also exhibited an inverse relationship with the dependent variable compared to the result obtained in the base model, the outcome still provided little support for the hypothesis: the sensitivity model shows CEO duality to be negatively associated with NPM but not significant statistically.

Table 3 presented the results of the second cluster. Board structure and macroeconomic variables were regressed against the firm performance proxy (Tobin's $q$ ). The results show the base model to be robust and offered high explanatory power, as reflected in the $\mathrm{R}^{2}$ and F-statistic (0.871 and 14.274). The $\mathrm{p}$-value, 0.000 , which is less than the 0.05 level, also suggests that the base model is statistically significant. The $\mathrm{R}^{2}$ value of $0.871 \mathrm{implies}$ that the variables used in the model explain up to 87 per cent of the relationship between the independent variables and dependent variable.

\begin{tabular}{|c|c|c|c|}
\hline \multirow[t]{2}{*}{ Variable } & Base Model (Tobin's q) & & Sensitivity Model (ROA) \\
\hline & OLS Result & & OLS Result \\
\hline \multirow[t]{2}{*}{ Constant } & 9.878 & & -0.805 \\
\hline & $(-1.318)$ & & $(-0.103)$ \\
\hline \multirow[t]{2}{*}{ BS } & 0.052 & & 0.135 \\
\hline & $(0.454)$ & & (1.281) \\
\hline \multirow[t]{2}{*}{ AVGEXP } & $0.164^{a}$ & & $0.175^{a}$ \\
\hline & (2.154) & & $(2.396)$ \\
\hline \multirow[t]{2}{*}{ BI } & $0.103^{a}$ & & -0.081 \\
\hline & $(1.343)$ & & $(-1.077)$ \\
\hline \multirow[t]{2}{*}{ CEODUAL } & 0.035 & & -0.062 \\
\hline & $(0.544)$ & & $(-0.920)$ \\
\hline \multirow[t]{2}{*}{ DMBA } & $0.272^{a}$ & & 0.022 \\
\hline & $(3.694)$ & & $(0.308)$ \\
\hline \multirow[t]{2}{*}{ ER } & 0.026 & & -0.058 \\
\hline & $(0.236)$ & & $(-0.577)$ \\
\hline \multirow[t]{2}{*}{$\operatorname{LOGGDP}(-1)$} & -1.156 & & -0.236 \\
\hline & $(-1.474)$ & & $(-0.289)$ \\
\hline \multirow[t]{2}{*}{ LOGOPENNESS(-1) } & $0.128^{a}$ & & $0.149^{a}$ \\
\hline & (1.635) & & $(1.822)$ \\
\hline \multirow[t]{2}{*}{ LEV } & $0.023^{a}$ & FS & $1.128^{a}$ \\
\hline & (2.332) & & (1.933) \\
\hline $\mathrm{R}^{2}$ & 0.871 & & 0.742 \\
\hline Adjusted $\mathrm{R}^{2}$ & 0.751 & & 0.675 \\
\hline$F$-statistics & 14.273 & & 7.216 \\
\hline$P$-Value (F-statistics) & 0.00 & & 0.00 \\
\hline \multicolumn{4}{|c|}{ Notes: a significant at $5 \%$ level; $\boldsymbol{b}$ significant at $10 \%$ level; $t$-statistics values captured in parentheses } \\
\hline \multicolumn{4}{|c|}{$\begin{array}{l}\text { ROA is measured as the ratio of net profit to a firm's total assets. NPM is measured as the proportion of sales to net profit. Tobin's q is } \\
\text { derived as the ratio of a firm's market capitalisation to total assets. Board size is estimated as the total number of directors on the board. } \\
\text { Board Independence is captured as the total number of independent NEDs on the board. CEO Duality is captured as a dummy, which } \\
\text { takes the value one if the same person holds the two positions and the value zero if the positions are separated. DMBA is captured as } \\
\text { the number of directors with an MBA. AVGEXP is captured as the average number of years of work experience of the directors. ER is } \\
\text { captured as the proportion of directors from the three major ethnic groups in Nigeria. Economic growth is captured as the percentage } \\
\text { change in the real GDP year-on-year. Economic Openness is measured as the ratio of the balance of trade to GDP. Firm Leverage is } \\
\text { measured as the ratio of firm debt to assets. }\end{array}$} \\
\hline
\end{tabular}

With respect to the performance of the individual variables that made up the regressors, five variables were found to be statistically significant. These were directors' years of experience (AVGEXP), board independence (BI) and directors' qualifications (DMBA), leverage (LEV) and economic openness (LOGOPENNESS). Board size (BS), CEO duality (CEODUAL) and directors' ethnic representation, as well as the level of economic growth (LOGGGDP), were found to be statistically immaterial at the 5 per cent level of significance. The results regarding the effect of 
the relationships were equally significant. Board size was found to have a positive effect on Tobin's q, contrary to the prediction of Hypothesis 1, but the effect was statistically insignificant (coefficient $=0.052 ; \mathrm{p}$-value $=0.650$ ). Directors' years of experience was found to be positively and significantly associated with Tobin's $q$ (coefficient $=0.164 ; \mathrm{p}$-value $=0.032$ ).

This result offers empirical support to the fifth hypothesis. Board independence was found to be strongly and significantly linked to firm performance. This outcome is consistent with the second hypothesis. Hypothesis 3's prediction of the effect of firm leadership structure (CEO duality) is not authenticated. CEO duality was found to be positively but insignificantly associated with the performance measure. Directors' educational qualifications (DMBA) were found to be significantly associated with Tobin's $q$ (coefficient $=0.272$; p-value $=0.005$ ) thus offering support for the fourth hypothesis. On the contrary, directors' ethnicity (ER) was found to be positively linked to firm performance as predicted in the sixth hypothesis, but the effect was statistically insignificant.

A further sensitivity analysis was conducted to verify whether the results obtained from the base model of Cluster 2 were sensitive to the performance measure employed, i.e. Tobin's $q$ (see Table 3). The alternative model was regressed using a different performance measure (ROA) and with an additional control variable (firm size) to mitigate potential endogeneity. The overall outcome shows the model to have high explanatory power and robustness. The adjusted $\mathrm{R}^{2}$ is 0.675 , suggesting that nearly 68 per cent of the variation in the dependent variable (ROA) is explained by the estimated model. This is further corroborated by the $\mathrm{R}^{2}$ (=74 per cent).

In terms of the relative effects of the explanatory variables on the dependent variable, directors' years of experience (AVGexp) was found to be statistically significant at the 5 per cent level. This result implies that, consistent with the fifth hypothesis, directors' years of experience are indeed positively associated with ROA. Board size (BS) and the proportion of directors with an MBA were found be positively associated with ROA, as expected, but statistically insignificant. The relationship between CEO duality (CEODUAL) and firm performance has the sign predicted in the third hypothesis but also not statistically significant (coefficient $=-0.062$; $t$-statistic $=-0.920$ ). Board independence is negatively associated with ROA but not significant (coefficient $=-0.081$; $\mathrm{t}$ statistic $=-1.077)$. Regression result of from sensitivity model offered no support for the strategic relevance of ethnic representation (ER) to firm performance.

\subsection{Post-diagnostic results}

The regression results obtained in the preceding models were further subjected to post-diagnostic evaluations to reaffirm their validity, reliability and long-term sustainability. A co-integration test result showed a high level of statistical significance. The reported p-value was 0.011 (coefficient $=0.018$; t-statistic $=1.594$ ). This result implies that all of the explanatory variables captured in the model, and the subsequent series of results obtained under various scenarios that examined their effects on firm performance are sustainable in the long term (see: Appendix 6). The second post-diagnostic test conducted was a static forecast experiment using the Theil inequality coefficient (see Table 4). The rationale behind this reliability test was to check the effectiveness of the model in reflecting future changes in the explained variables. Across the four dependent variables employed in this study, the Theil inequality coefficients were greater than zero but also less than one, which implies a relatively good fit.

\begin{tabular}{lccc}
\hline & Table 4: Static forecast tests of model reliability & ROA \\
\hline Variables & NPM & Tobin's q & 0.707 \\
\hline Theil Inequality Coefficient & 0.636 & 0.663 & 0.000 \\
Bias Proportion & 0.000 & 0.000 & 0.500 \\
Variance Proportion & 0.405 & 0.440 & 0.500 \\
Covariance Proportion & 0.595 & 0.560 & \\
\hline
\end{tabular}

The Theil coefficient results are further divided into three proportions: bias, variance and covariance. The results from the division process show an absence of systematic bias (see: Table 4 above), which implies that the mean of the forecast and the mean of the actual series were not significantly far apart, but almost equal. Therefore, the estimated models used in this study are statistically valid. In addition, the overall residual variance proportion is relatively low, which suggests that the fluctuations seen in the estimated models had occurred by chance. Thus, the pattern of results observed and documented in terms of the effects of the independent variables on the dependent variables are sustainable (see: Theil 1966). 


\subsection{Discussion of results}

The study has focused on establishing whether SEC Code-recommended board characteristics and macroeconomic variables are linked with improved firm performance in Nigeria. Several findings have emerged across the two clusters of the estimated models. Diverse results from a single study are not peculiar to this empirical investigation, but rather widely documented in corporate governance studies (e.g. Jackling and Johl 2009; Arslan et al. 2010; Anderson et al. 2011). Board size had maintained its positive but insignificant relationship with the firm performance measures Tobin's $q$ and ROA respectively. This study thus concludes that the Hypothesis 1 prediction of a negative association between board size and firm performance is invalid in the Nigerian context. This outcome is consistent with previous empirical evidences (e.g. Tanna et al. 2011; Larmou and Vafeas 2010).

Board independence was found to be positively associated with firm value and statistically significant at the 5 per cent level. Even when the sign of the relationship became negative during the sensitivity assessment, the resultant change was not statistically significant to invalidate the market value (Tobin's $q$ ) outcome. Therefore, this study has found credible evidence in support of Hypothesis 2, in that the presence of independent NEDs is vital to improving the performance of listed companies in Nigeria. This outcome is very much consistent with previous empirical studies examining the effects of board independence on firm performance (see: Jackling and Johl 2009; Rhoades et al. 2000). Regarding leadership structure, the study found neither significant support for Hypothesis 3 or evidence to justify the presumption that CEO duality is a key determinant of firm performance in Nigeria. This finding is clearly consistent with previous empirical evidence in both developed and emerging economies (see: Arslan et al. 2010; Baliga et al. 1996; Boyd 1995).

The presence of directors with MBA was found to be positively and statistically significantly linked to firm market value (Tobin's $q$ ). In addition, the results obtained using the accounting-based measures (NPM and ROA) were both not significant enough to invalid the outcome from Tobin's $q$ (see: Shan and McIver 2011). Therefore, the Hypothesis 4 prediction, which suggested that MBA qualifications are significantly linked to improved firm performance in Nigeria, was sustained. However, the study acknowledges that the sign of this relationship tends to vary across performance measures. This finding is consistent with previous studies (e.g. Darmadi 2013; Anderson et al. 2011; Rakhmayil and Yuce 2008).

Directors' years of experience was found to be significantly linked to firm performance across the measures. Interestingly, this is the only board variable whose level of statistical significance was sustained across Clusters 1 and 2. The study found overwhelming evidence to suggest that board members' experience, one of the indicators of cognitive diversity, is relevant and a key determinant of firm performance in Nigeria. Hypothesis 5 was thus supported empirically. This evidence is consistent with previous studies on cognitive diversity (e.g. Lai and Chen 2012; Anderson et al. 2011). The final board variable tested was the effect of directors' ethnicity (Hypothesis 6). The study found that the directors' ethnic representation was statistically insignificant to firm performance across the measures (i.e. both market and accounting-based). While the study acknowledges the importance of directors' demography on a firm's operations, the effect of such configuration seems to be immaterial when it comes to creating value for the firm. The finding on directors' ethnicity is consistent with the outcomes from previous studies on demographic diversity (e.g. Carter et al. 2010; Hagendorff and Keasey 2010; Randoy et al. 2006).

Whereas the level of economic growth was found to be statistically insignificant, the degree of economic openness was found to be strongly linked to firm performance. This result points to the effects of FDI on the performance of local companies in both small and emerging economies (see: Symeou 2009). Trade liberalisation is an important factor relating to the sustainable performance of firms in Nigeria, especially those quoted on the NSE. This finding is consistent with some previous studies that examined the combined effect of corporate governance and macroeconomic variables on firm performance (e.g. Naceur et al. 2007; Boubakri et al. 2005; D'Souza et al. 2005). This result further explains why the explanatory power of the models used in this study increased when the external variables relating to the state of the economy were introduced, as seen in Cluster 2.

Overall, the results from the estimated models were impressive in providing empirical answers to the fundamental research questions posed at the beginning of this study, and in laying a solid foundation that could guide future research on the nature of the relationship between the board and firm performance in the Nigerian context. In summary, the empirical answers to the key research questions are as follows:

H1: On whether adherence to the SEC Code in terms of board configuration, predict firm performance in Nigeria, the study found significant evidences of relationships between board independent, directors' academic qualification, professional experience and the measures of performance. 
H2: Regarding which of the specific board features has the most significant influence on performance, the study found board independence in terms of the proportion of independent NEDs to be the most crucial element of board effectiveness in Nigeria.

H3: Relating to whether there any other explanatory variables outside the board factors that significantly drive these performance variations, the study found that the inclusion of macroeconomic variables in the estimated models increased their explanatory power from an average of 65 to 84 per cent. This study argued that, in the Nigerian context, external economic forces particularly, the degree of economic openness is a key determinant that needs to be taken into account in model estimation when investigating the relationship between board features and firm performance. The explanatory power of the models used in previous empirical studies in Nigeria is extremely weak and inadequate compared to the level achieved in this study (e.g. Kajola 2008).

\subsection{Theoretical and practical implications of the findings}

Findings from this study have three key implications that are rooted in the existing corporate governance theories. The first implication relates to the methodological approach used to study the board to firm performance relationship. Significant numbers of previous studies have relied on simplistic theoretical assumptions of linear relationships. However, the causality between the board characteristics and firm performance seems to be much more complicated than these theories have hypothesised (see: Nicholson and Kiel 2007). While the present study has found evidence suggesting that some specific board characteristics are linked to improved firm performance, the statistical levels of significance of these relationships are very weak in the absence of moderating variables, most of which are external to the firm. The explanatory power of the estimated models (i.e. $R^{2}$ and $R^{2}$ adjusted) used in this study, when macroeconomic variables were introduced as determinants of firm performance, ranged between 64 per cent and 87 per cent. The explanatory efficacy of these models is 30 to 50 per cent higher than those used in most previous studies that have assumed direct relationship between specific board features and measures of performance (e.g. Guest 2009; Kajola 2008; Mak and Kusnadi 2005). The assumption of ceteris paribus, corporate governance being the only determinant of firm performance, can be deceptive, especially in the context of emerging economies (see: Ugur and Ararat 2006; D’Souza et al. 2005; Boubakri et al. 2005). Researchers must begin to recognise, and capture in their estimation models, those variables that account for the interplay between firms' internal and external environments (see: Nicholson and Kiel 2007).

Second, the agency theory has received significant attention in corporate governance discourse, especially the issue of independent leadership structure. This study, however, found no empirical support for the separation of leadership as hypothesised in agency theory and recommended in the SEC Code. Ninety-eight per cent of firms in the data sample had adopted a non-dual leadership style with the positions of CEO and board chair held by two different individuals (see: Appendix 1). But, across the estimated models, no statistically significant results were recorded regarding the economic benefits associated with the adoption of such paradigm. This study's findings add to the growing empirical evidence suggesting that CEO duality or non-duality is contingent on firm-specific characteristics, as investors remain somewhat indifferent to the style of leadership firms adopt (see: Baliga et al. 1996; Dahya and Travlos 2000). It was observed, based on the pattern of data collected on CEO duality, that some firms have adopted a clear independent leadership structure in those industries that specifically require high technical expertise, such as construction, IT, health care and oil and gas. The bulk shareholders in these subsectors have assumed the position of board chair in their respective companies, whilst an independent person is appointed as CEO to run the affairs of the firm. Interestingly, the study found significant statistical evidence that the proportion of independent NEDs is linked to increased firm performance in Nigeria. While this result offers support to the agency theory, this study has attributed the relationship to firms' desire for resource co-optation, rather than for monitoring the CEO-led executives. This explains why similar results were obtained regarding the effects of the board cognitive diversity elements (i.e. directors' educational qualifications and experience) on firm performance. Peng (2004) argued that, in transition economies, NEDs play more of a resource dependency role than a role of monitoring the executives. Nigerian corporate boards may look well-configured and in line with the agency orientation but, in actual fact, the roles these directors are brought in to play differ significantly from the agency theory-based roles.

Third, the study findings also have implications for the board diversity debate, from both the resource dependency and stakeholder perspectives. In support of the resource dependency theory, the study offers significant evidence linking directors' competences with firm performance. The proportion of directors with MBA and their years of experience are both associated with increased market value (Tobin's q). However, no substantial evidence was recorded with regard to the relevance of ethnic diversity at the board level. This implies that, in the Nigerian context, the business case for board diversity, through the increased involvement of competent directors with appropriate educational qualifications and backgrounds/experience, takes precedence over ethnic considerations. The lack of empirical support for the importance of directors' ethnicity in this study does not undo the arguments put forward by board equality debaters but rather points to the fact that, in an emerging economy 
striving towards the attainment of developmental goals, demographic variables play a less significant role in determining who does what in the corporate environment.

\subsection{Conclusion}

This study has documented significant empirical evidence on the relevance of board independence and directors' competence in firm governance. The presence of independent NEDs and directors with specific educational qualifications (MBA) and professional experience were found to be vital instruments in improving a firm's market valuation and performance. While the contribution of this study in the area of board independence is more one of validating previous empirical findings, the evidence recorded here regarding directors' educational qualification and experience is crucial to the emerging debate on the strategic relevance of directors' competencies in firm governance. This study offers support for the business case for diversity, while rejecting the equality case for board heterogeneity. From the theoretical viewpoint, the agency and resource dependency theories of corporate governance were empirically supported in this study, with a high statistical level of significance achieved regarding the relevance of board independence and cognitive competence. The findings from these two key variables would provide corporate regulators in the emerging economies especially those in Nigeria, with an empirically proven lead that can help to guide future policy prescriptions in the area of corporate governance.

Finally, this study has added methodological originality to corporate governance research through the adoption of an integrated approach using three stages of analytical procedures (i.e. pre-diagnostic tests, regression analysis and post-diagnostic tests) to arrive at the final empirical results. The application of extensive econometric tools in single piece of corporate governance research is not a common phenomenon in this field of study, but rather an emerging trend with the approach mostly visible in those research works published over the last ten years (e.g. Peng 2007).

In terms of future study directions, the Nigerian corporate environment offers several untapped opportunities for the development of new research frameworks on the dichotomy of board dynamics and firm performance. This study thus calls for more corporate governance research with an emphasis on both internal and external mechanisms. Future studies are encouraged to pay equal attention to board structure and drilling down into the configuration of board committees (see: Pacini et al. 2008). Because of the constraints on holding board meetings as regularly as might be expected, much board business is being carried out at the committee level. It would be interesting to examine the composition of board committees and their relationship with firm performance. Board diversity originating from directors' demographic and cognitive features has been a subject of public debate in relation to corporate governance, mostly in developed economies. However, this study's findings of a significant relationship between cognitive variables (i.e. the directors' experience and educational qualifications) and firm performance opens up a new paradigm on board structure discourse in Nigeria. This study encourages further research in the two major areas of the diversity debate, but especially in that relating to directors' competencies. The literature on cognitive diversity remains very limited compared to that addressing the demographic elements.

\section{References}

Adam, A. M., \& Shavit, T. (2009). Roles and responsibilities of boards of directors revisited in reconciling conflicting stakeholders' interests while maintaining corporate responsibility. Journal of Management and Governance, 13(4), 281-302. http://dx.doi.org/10.1007/s10997-008-9076-3

Ahunwan, B. (2002). Corporate governance in Nigeria. Journal of Business Ethics, 37(3), 269-287. http://dx.doi.org/10.1023/A:1015212332653

Al-Haddad, W.M.Y., Alzurqan, S.T., \& Al_Sufy F. J. (2011). The effect of corporate governance on the performance of Jordanian industrial companies: an empirical study on the Amman Stock Exchange. International Journal of Humanities and Social Science, 1(4), 56-69.

Anderson, R. C., Reeb, D. M., Upadhyay, A., \& Zhao W. (2011). The economics of director heterogeneity. Financial Management, 40(1), 5-38. http://dx.doi.org/10.1111/j.1755-053X.2010.01133.x

Arslan, Ö., Karan, M. B., \& Ekşi C. (2010). Board structure and corporate performance. Managing Global Transitions, 8(1), 3-22.

Baliga, B. R., Moyer R. C., \& Rao, R. S. (1996). CEO duality and firm performance: what's the fuss? Strategic Management Journal, 17(1), 41-53. http://dx.doi.org/10.1002/(SICI)1097-0266(199601)17:1<41::AIDSMJ784>3.0.CO;2-\#

Bennedsen, M., Kongsted, H. C., \& Nielsen, K. M. (2008). The causal effect of board size in the performance of smalland medium-sized firms. Journal of Banking and Finance, 32(6), 1098-1109. http://dx.doi.org/10.1016/j.jbankfin.2007.09.016 
Berghe, L. A., \& Levrau, A. (2004). Evaluating boards of directors: what constitutes a good corporate board. Corporate Governance: An International Review, 12(4), 461-478. http://dx.doi.org/10.1111/j.14678683.2004.00387.x

Bhagat, S., Bolton, B. J., \& Subramanian, A. (2010). CEO Education, CEO Turnover, and Firm Performance. http://papers.ssrn.com/sol3/papers.cfm?abstract_id=1670219. Accessed 5 October 2012.

Bhagat, S., \& Black, B. (2000). Board Independence and Long-Term Firm Performance. Law and Economics Working Paper No. 143, New York: The Centre for Law and Economics Studies at CLS.

Boubakri, N., Cosset, J.C., \& Guedhami, O. (2005). Liberalisation, corporate governance and the performance of privatised firms in developing countries. Journal of Corporate Finance, 11(5), 767-790. http://dx.doi.org/10.1016/j.jcorpfin.2004.05.001

Boyd, B. K. (1995). CEO duality and firm performance: A contingency model. Strategic Management Journal, 16(4), 301-312. http://dx.doi.org/10.1002/smj.4250160404

Bozec, R. (2005). Boards of directors, market discipline and firm performance. Journal of Business Finance and Accounting, 32(9 and 10), 1921-1960. http://dx.doi.org/10.1111/j.0306-686X.2005.00652.x

Bulent, G. (2009). The 2008 World Economic Crisis: Global Shifts and Fault Lines. http://www.globalresearch.ca/index.php?context=va\&aid=12283. Accessed 7 June 2010.

Byrd, J. W., \& Hickman, K. A. (1992). Do outside directors monitor managers? Journal of Financial Economics, 32(2), 195-221. http://dx.doi.org/10.1016/0304-405X(92)90018-S

Cadbury, S.A. (2000). The corporate governance agenda. Corporate Governance: An International Review, 8(1), 7-15. http://dx.doi.org/10.1111/1467-8683.00175

Campbell, K., \& Mínguez-Vera, A. (2008). Gender diversity in the boardroom and firm financial performance. Journal of Business Ethics, 83(3), 435-451. http://dx.doi.org/10.1007/s10551-007-9630-y

Carter, D. A., D'Souza, F., Simkins, B. J. \& Simpson, W. G. (2010). The gender and ethnic diversity of US boards and board committee and firm financial performance. Corporate Governance: An International Review, 18(5), 396-414. http://dx.doi.org/10.1111/j.1467-8683.2010.00809.x

Carter, D. A., Simkins, B. J. \& Simpson, W. G. (2003). Corporate governance, board diversity, and firm value. The Financial Review, 38(1), 33-53. http://dx.doi.org/10.1111/1540-6288.00034

CBN, (2011). On capitalization of eight Nigerian banks. Abuja: Central Bank of Nigeria.

Chen, R, M., Dyball, C., \& Wright, S. (2009). The link between board composition and corporate diversification in Australian corporations. Corporate Governance: An International Review, 17(2), 208-223. http://dx.doi.org/10.1111/j.1467-8683.2009.00734.x

Chenhall, R.H., \& Moers, F. (2007). The issue of endogeneity within theory-based, quantitative management accounting research. European Accounting Review, 173-195. http://dx.doi.org/10.1080/09638180701265937

Coles, J. L., Daniel, N. D., \& Naveen, L. (2008). Boards: does one size fit all? Journal of Financial Economics, 87(2), 329-356. http://dx.doi.org/10.1016/j.jfineco.2006.08.008

Dahya, J., \& Travlos, N.G. (2000). Does the one-man-show pay? Theory and evidence on the dual CEO revisited. European Financial Management, 6(1), 85-98. http://dx.doi.org/10.1111/1468-036X.00113

Dalton, D. R., Daily, C. M., \& Ellstrand, A. E., \& Johnson, J. L. (1998). Meta-analytic reviews of board composition, leadership structure, and financial performance. Strategic Management Journal, 19(3), $269-290$. http://dx.doi.org/10.1002/(SICI)1097-0266(199803)19:3<269::AID-SMJ950>3.0.CO;2-K

Darmadi, S. (2013). Board members' education and firm performance: evidence from a developing economy. International Journal of Commerce and Management, 23(2), 113-135. http://dx.doi.org/10.1108/10569211311324911

D'Souza, J., Megginson, W., \& Nash, R. (2005). Effect of institutional and firm-specific characteristics on postprivatisation performance: evidence from developed countries. Journal of Corporate Finance, 11(5), 747766. http://dx.doi.org/10.1016/j.jcorpfin.2004.12.001

Egene, G. (2009). Nigeria: SEC Probes AP's Share Manipulation Allegation. THISDAY, 26 March, p. 10.

Eklund, J. E., Palmberg, J., \& Wiberg, D. (2009). Ownership Structure, Board Composition and Investment. Working Paper No. 172, Stockholm: Centre of Excellence for Service and Innovation Studies (CESIS).

Elsayed, K. (2011). Board size and corporate performance: the missing role of board leadership. Journal of Management and Governance, 15(3), 415-446. http://dx.doi.org/10.1007/s10997-009-9110-0

Elsayed, K. (2007). Does CEO duality really affect corporate performance? Corporate Governance: An International Review, 15(6), 1203-1214. http://dx.doi.org/10.1111/j.1467-8683.2007.00641.x

El Sood, H.S.A. (2008). The usefulness of accounting information, economic variables and corporate governance measures to predict corporate failure. The Journal of Applied Business Research, 24(4), 1-10.

Fairchild, L., \& Li, J. (2005). Director quality and firm performance. The Financial Review, 40(2), $257-279$. http://dx.doi.org/10.1111/j.1540-6288.2005.00102.x

Faleye, 0. (2007). Does one hat fit all? The case of corporate leadership structure. Journal of Management Governance, 11(3), 239-259. http://dx.doi.org/10.1007/s10997-007-9028-3 
Finegold, D., Benson, G. S., \& Hecht, D. (2007). Corporate boards and company performance: review of research in light of recent reforms. Corporate Governance: An International Review, 15(5), 865-878. http://dx.doi.org/10.1111/j.1467-8683.2007.00602.x

Gill, A., Biger, N., \& Bhutani, S. (2008). Corporate performance and the chief executive officer's compensation in the service industry. The Open Business Journal, 1(1), 62-66. http://dx.doi.org/10.2174/1874915100801010062

Gomez-Mejia, L., Balkin, D. \& Cardy, A. R. (2005). Management. New York: McGraw-Hill.

Goodstein, J., Gautam, K. \& Boeker, W. (1994). The effects of board size and diversity on strategic change. Strategic Management Journal, 15(3), 241-250. http://dx.doi.org/10.1002/smj.4250150305

Granger, C. W. J. (1969). Investigating causal relations by econometric models and cross-spectral methods. Econometrica, 37(3), 424-438. http://dx.doi.org/10.2307/1912791

Guest, P. M. (2009). The impact of board size on firm performance: evidence from the UK. The European Journal of Finance, 15(4), 385-404. http://dx.doi.org/10.1080/13518470802466121

Hagendorff, J., \& Keasey, K. (2010). The value of board diversity in banking: evidence from the market for corporate control. The European Journal of Finance, 18(1), 41-58. http://dx.doi.org/10.1080/1351847X.2010.481471

Hermalin, B. E., \& Weisbach, M.S. (1988). The determinants of board composition. RAND Journal of Economics, 19(4), 589-606. http://dx.doi.org/10.2307/2555459

Hermalin, B., \& Weisbach, M. (2003). Boards of directors as an endogenously determined institution: a survey of the economic literature. Federal Reserve Bank of New York Policy Review, 9(1), 7-26.

Hsu, H.E. (2010). The relationship between board characteristics and financial performance: an empirical study of United States initial public offerings. International Journal of Management, 27(2), 332-341.

Jackling, B., \& Johl, S. (2009). Board structure and firm performance: evidence from India's top companies. Corporate Governance: An International Review, 17(4), 492-509. http://dx.doi.org/10.1111/j.14678683.2009.00760.x

Jalbert, T., Rao, R. \& Jalbert, M. (2002). Does school matter? An empirical analysis of CEO education, compensation, and firm performance. International Business and Economics Research Journal, 1(1), 83-98.

John K., \& Senbet, L.W. (1998). Corporate governance and board effectiveness. Journal of Banking and Finance, 22(4), 371- 403. http://dx.doi.org/10.1016/S0378-4266(98)00005-3

Kajola, S.O. (2008). Corporate governance and firm performance: the case of Nigerian listed firms. European Journal of Economics, Finance and Administrative Sciences, 14(4), 16-28.

Kang, H., Cheng, M. \& Gray, S. J. (2007). Corporate governance and board composition: diversity and independence of Australian boards. Corporate Governance: An International Review, 15(2), $194-207$. http://dx.doi.org/10.1111/j.1467-8683.2007.00554.x

Kim, H. \& Lim, C. (2010). Diversity, outside directors and firm valuation: Korean evidence. Journal of Business Research, 63(3), 284-291. http://dx.doi.org/10.1016/j.jbusres.2009.01.013

Kim, Y. (2007). The proportion and social capital of outside directors and their impacts on firm value: evidence from Korea. Corporate Governance: An International Review, 15(6), 1168-1176. http://dx.doi.org/10.1111/j.1467-8683.2007.00638.x

Klapper, L.F., \& Love, I. (2004). Corporate governance, investor protection, and performance in emerging markets. Journal of Corporate Finance, 10(5), 703-728. http://dx.doi.org/10.1016/S0929-1199(03)00046-4

Krambia-Kapardis, M., \& Psaros, J. (2006). The implementation of corporate governance principles in an emerging economy: a critique of the situation in Cyprus. Corporate Governance: An International Review, 14 (2), 126139. http://dx.doi.org/10.1111/j.1467-8683.2006.00492.x

Lai, J., \& Chen, L. (2012). Does board experience matter? Evidence from foreign direct investment. Journal of Service Science and Management, 5(2), 140-150. http://dx.doi.org/10.4236/jssm.2012.52018

Laing, D., \& Weir, C. M. (1999). Governance structures, size and corporate performance in UK firms. Management Decision, 37(5), 457-464. http://dx.doi.org/10.1108/00251749910274234

Lam, T.Y., \& Lee, S.K. (2008). CEO duality and firm performance: evidence from Hong Kong. Corporate Governance, 8(3), 299-316. http://dx.doi.org/10.1108/14720700810879187

Larmou, S., \& Vafeas, N. (2010). The relation between board size and firm performance in firms with a history of poor operating performance. Journal of Management and Governance, 14(1), 61-85. http://dx.doi.org/10.1007/s10997-009-9091-z

Lawal, B. (2012). Board dynamics and corporate performance: review of literature, and empirical challenges. International Journal of Economics and Finance, 4(1), 22-35.

Lipton, M., \& Lorsch, J. W. (1992). A modest proposal for improved corporate governance. Business Lawyer, 48(1), 59-77.

Luan, C. J., \& Tang, M.J. (2007). Where is independent director efficacy? Corporate Governance: An International Review, 15(4), 636-643. http://dx.doi.org/10.1111/j.1467-8683.2007.00593.x

Lückerath-Rovers, M. (2011). Women on boards and firm performance. Journal of Management and Governance, 17(2), 491-509. http://dx.doi.org/10.1007/s10997-011-9186-1 
Mak, Y., \& Kusnadi, Y. (2005). Size really matters: further evidence on the negative relationship between board size and firm value. Pacific-Basin Finance Journal, 13(3), 301-318. http://dx.doi.org/10.1016/j.pacfin.2004.09.002

Markarian, G., \& Parbonetti, A. (2007). Firm complexity and board of director composition. Corporate Governance: An International Review, 15(6), 1224-1243. http://dx.doi.org/10.1111/j.1467-8683.2007.00643.x

Marmol, F., \& Velasco, C. (2004). Consistent testing of co-integrating relationships. Econometrica, 72(6), 18091844. http://dx.doi.org/10.1111/j.1468-0262.2004.00554.x

Meyer, M. (2002). Rethinking Performance Measurement: Beyond the Balanced Scorecard. Cambridge: University Press.

Mura, R. (2007). Firm performance: do non-executive directors have minds of their own? Evidence from UK panel data. Financial Management, 36(3), 81-112. http://dx.doi.org/10.1111/j.1755-053X.2007.tb00082.x

Muth, M. M., \& Donaldson, L. (1998). Stewardship theory and board structure: a contingency approach. Corporate Governance: An International Review, 6(1), 5-28. http://dx.doi.org/10.1111/1467-8683.00076

Naceur, S.B., Ghazouani, S. \& Omran, M. (2007). The performance of newly privatised firms in selected MENA countries: the role of ownership structure, governance and liberalisation policies. International Review of Financial Analysis, 16(4), 332-353. http://dx.doi.org/10.1016/j.irfa.2006.09.006

Nicholson, G. J., \& Kiel, G. C. (2007). Can directors impact performance? A case-based test of three theories of corporate governance. Corporate Governance: An International Review, 15(4), 585-608. http://dx.doi.org/10.1111/j.1467-8683.2007.00590.x

Nielsen, S., \& Huse, M. (2010). The contribution of women on boards of directors: Going beyond the surface. Corporate Governance: An International Review, 18(2), 136-148. http://dx.doi.org/10.1111/j.14678683.2010.00784.x

Nordberg, D. (2011). Corporate Governance and the Board. In S. Idowu., \& Louche, C. Theory and Practice of Corporate Social Responsibility. Verlag Berlin Heidelberg: Springer, pp. 39-53. http://dx.doi.org/10.1007/978-3-642-16461-3_3

Ocran, M.K., \& Biekpe, N. (2007). Forecasting volatility in Sub-Saharan Africa's commodity markets. Investment Management and Financial Innovations, 4(2), 91-102.

OECD, (2004). Principle of Corporate Governance. France: OECD.

Ongore, V. O., \& K'Obonyo, P.O. (2011). Effects of selected corporate governance characteristics on firm performance: empirical evidence from Kenya. International Journal of Economics and Financial Issues, 1(3), 99-122.

Pacini, C., Hillison, W., \& Marlett D. (2008). Board size and firm performance in the property-liability insurance industry. Research in Finance, 24(1), 249-285. http://dx.doi.org/10.1016/S0196-3821(07)00210-9

Peng, M. W. (2004). Outside directors and firm performance during institutional transition. Strategic Management Journal, 25(5), 453-471. http://dx.doi.org/10.1002/smj.390

Peng, M.W., Zhang, S., \& Li, X. (2007). CEO duality and firm performance during China's institutional transitions. Management and Organisation Review, 3(2), 205-225. http://dx.doi.org/10.1111/j.17408784.2007.00069.x

Perry, T., \& Shivdasani, A. (2005). Do boards affect performance? Evidence from corporate restructuring. Journal of Business, 78(4), 1403-1431. http://dx.doi.org/10.1086/430864

Pfeffer, J. (1994). Competitive Advantage through People. Boston: Harvard Business School.

Pfeffer, J., \& Salancik, G. (1978). The External Control of Organisations: A Resource-Dependency Perspective. New York: Harper and Row.

Quadri, H. (2010). Conceptual framework for corporate governance in Nigeria- Challenges and panaceas. PM World Today, 12(9), 1-8.

Raithatha, M., \& Bapat, V. (2012). Corporate governance compliance practices of Indian companies. Research Journal of Finance and Accounting, 3(8), 19-26.

Rakhmayil, S., \& Yuce, A. (2008). Effects of manager qualification on firm value. Journal of Business \& Economics Research, 6(7), 129-138.

Randøy, T., Thomsen, S., \& Oxelheim, L. (2006). A Nordic Perspective on Corporate Board Diversity. Oslo: Nordic Innovation Centre.

Randøy, T., \& Jenssen, J. I. (2004). Board independence and product market competition in Swedish Firms. Corporate Governance: An International Review, 12(3), 281-289. http://dx.doi.org/10.1111/j.14678683.2004.00369.x

Razali, N.M., \& Wah, Y.B. (2011). Power comparisons of Shapiro-Wilk, Kolmogorov-Smirnov, Lilliefors and Anderson-Darling tests. Journal of Statistical Modeling and Analytics, 2(1), 21-33.

Rechner, P. L., \& Dalton, D. R. (1991). CEO duality and organisational performance: a longitudinal analysis. Strategic Management Journal, 12(2), 155-160. http://dx.doi.org/10.1002/smj.4250120206

Rhoades, D. L., Rechner, P. L., \& Sundaramurthy, C. (2000). Board composition and financial performance: a metaanalysis of the influence of outside directors. Journal of Managerial Issues, 12(1), 76-91. 
Rogers, P., Ribeiro, K.C.S., \& Securato, J.R. (2008). Corporate governance, stock market and economic growth in Brazil. Corporate Ownership and Control, 6(2), 222-237.

Rwegasira, K. (2000). Corporate governance in emerging capital markets: whiter Africa? Corporate Governance: An International Review, 8(3), 258-267. http://dx.doi.org/10.1111/1467-8683.00203

SEC, (2009). Code of Corporate Governance. Abuja: Nigeria Securities and Exchange Commission.

SEC, (2003). Code of Corporate Governance. Abuja: Nigeria Securities and Exchange Commission.

Shan, Y. G., \& McIver, R. P. (2011). Corporate governance in China: panel data evidence on listed non-financial companies. Asia Pacific Business Review, 17(3), 301-324. http://dx.doi.org/10.1080/13602380903522325

Symeou, P. (2009). The Effects of Economy Size on Firm Performance: Evidence from the Telecommunications Sector. Munich: Institute for Communication Economics.

Şener, İ., Varoğlu, A., \& Aren, S. (2011). Board composition and organisational performance: Environmental characteristics matter. Procedia Social and Behavioural Sciences, 24(1), 1481-1493. http://dx.doi.org/10.1016/j.sbspro.2011.09.130

Tanna, S., Pasiouras, F., \& Nnadi, M. (2011). The effect of board size and composition on the efficiency of UK banks. International Journal of the Economics of Business, 18(3), 441-462. http://dx.doi.org/10.1080/13571516.2011.618617

Theil, H. (1966). Applied Economic Forecasting. Amsterdam: North-Holland Publishing Co.

Tian, J. J., \& Lau, C.M. (2001). Board composition, leadership structure and performance in Chinese shareholding companies. Asia Pacific Journal of Management, 18(2), 245-263. http://dx.doi.org/10.1023/A:1010628209918

Uadiale, O. M. (2010). The impact of board structure on corporate financial performance in Nigeria. International Journal of Business and Management, 5(10), 155-166.

Ugur, M., \& Ararat, M. (2006). Does macroeconomic performance affect corporate governance? Evidence from Turkey. Corporate Governance: An International Review, 14(4), 325-348. http://dx.doi.org/10.1111/j.14678683.2006.00510.x

Walt, N. v., \& Ingley, C. (2003). Board dynamics and the influence of professional background, gender and ethnic diversity of directors. Corporate Governance: An International Review, 11(3), 218-234. http://dx.doi.org/10.1111/1467-8683.00320

Wan, D., \& Ong, C. (2005). Board structure, process and performance: evidence from public-listed companies in Singapore. Corporate Governance: An International Review, 13(2), $277-290$. http://dx.doi.org/10.1111/j.1467-8683.2005.00422.x

Wanyama, S., Burton, B., \& Helliar, C. (2009). Frameworks underpinning corporate governance: evidence on Ugandan perceptions. Corporate Governance: An International Review, 17(2), 159-175. http://dx.doi.org/10.1111/j.1467-8683.2009.00730.x

Weir, C., Laing, D., \& McKnight, P. J. (2002). Internal and external governance mechanisms: their impact on the performance of large UK public companies. Journal of Business Finance \& Accounting, 29(5 and 6), 579-611. http://dx.doi.org/10.1111/1468-5957.00444

Wintoki, M. B., Linck, J.S. \& Netter, J. M. (2012). Endogeneity and the dynamics of internal corporate governance. Journal of Financial Economics, 105(3), 581-606. http://dx.doi.org/10.1016/j.jfineco.2012.03.005

Yammeesri, J., \& Herath, S. K. (2010). Board characteristics and corporate value: evidence from Thailand. Corporate Governance, 10(3), 279-292. http://dx.doi.org/10.1108/14720701011051910

Yawson, A. (2006). Evaluating the characteristics of corporate boards associated with layoff decision. Corporate Governance: An International Review, 14(2), 75-84. http://dx.doi.org/10.1111/j.1467-8683.2006.00488.x

Yermack, D. (1996). Higher market valuation of companies with a small board of directors. Journal of Financial Economics, 40(2), 185-211. http://dx.doi.org/10.1016/0304-405X(95)00844-5

\section{APPENDICES}




\begin{tabular}{|c|c|c|}
\hline Leade rs hip Structure & No. of Company & Rate (\%) \\
\hline CEO Duality & 3 & 2 \\
CEO Non-duality & 124 & 98 \\
\hline Total & $\mathbf{1 2 7}$ & $\mathbf{1 0 0 \%}$ \\
\hline Ethnic Dive rs ity & Ave rage Rep. & No. of Company \\
\hline Directors from Major Ethnic Groups & 8 & 127 \\
\hline \multicolumn{2}{|c|}{ Total } & $\mathbf{1 2 7}$ \\
\hline
\end{tabular}

\section{Appendix 2: Chow breakpoint stability test of board dynamics (Pre and Post SEC Code)}

Chow Breakpoint Test: 127

Null Hypothesis: No breaks at specified breakpoints

Varying Regressors: All equation variables

Equation Sample: 1180

\begin{tabular}{lllr}
\hline \hline F-statistic & 0.424 & Prob. F(6,95) & 0.861 \\
Log likelihood ratio & 2.830 & Prob. Chi-Square(6) & 0.830 \\
Wald Statistic & 2.546 & Prob. Chi-Square(6) & 0.863 \\
\hline \hline
\end{tabular}

Appendix 3: Cumulative sum of squares residual (CUSUM) test on break point shock results (Year 2004)

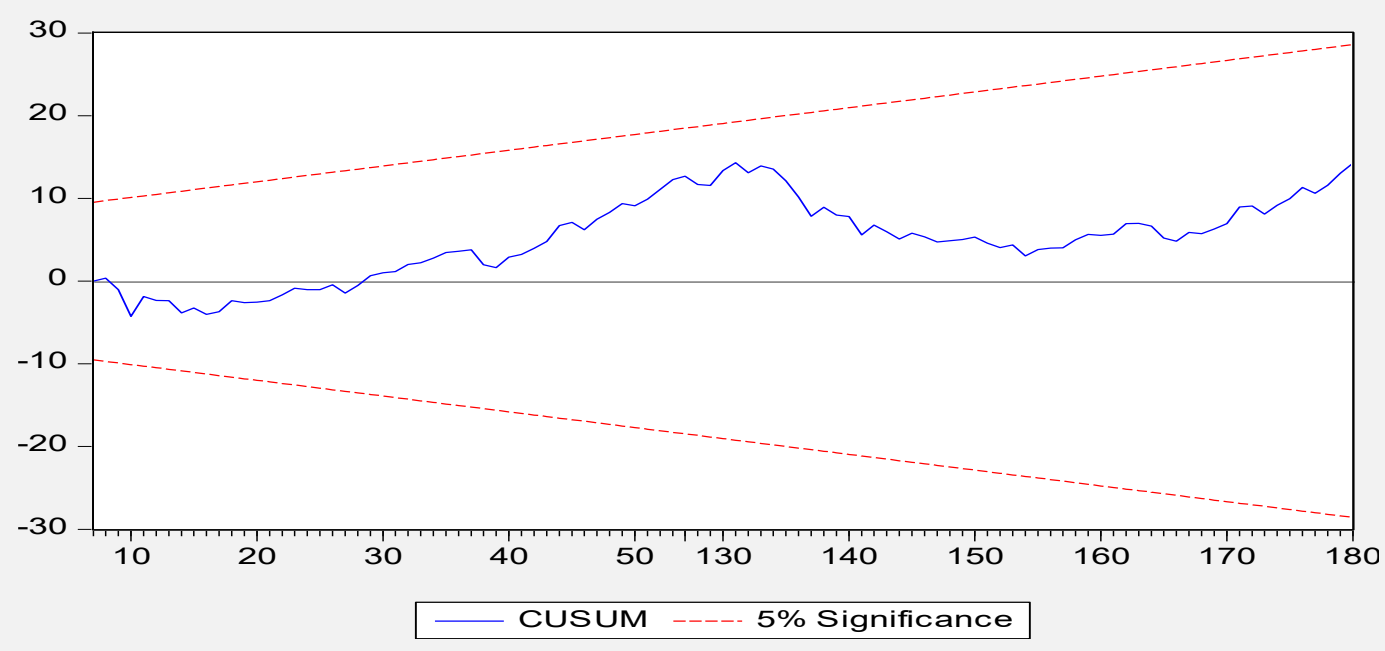

\begin{tabular}{|c|c|c|c|c|c|c|}
\hline \multicolumn{7}{|c|}{ Appendix 4: Normality test of the board variables (Z-standardized Values) } \\
\hline & BS & $\mathrm{BI}$ & CEOD & ER & AVGEXP & DMBA \\
\hline Mean & -0.005 & -0.000 & -0.001 & -0.004 & -0.003 & -0.002 \\
\hline Std. Dev. & 0.997 & 0.998 & 0.998 & 0.999 & 0.999 & 0.999 \\
\hline Skewness & 0.952 & 0.684 & -3.994 & 1.005 & 0.075 & 1.485 \\
\hline Kurtosis & 4.200 & 3.284 & 18.835 & 3.166 & 2.694 & 5.528 \\
\hline Jarque-Bera & 53.592 & 20.669 & 3329.218 & 43.079 & 0.585 & 67.833 \\
\hline Probability & 0.000 & 0.000 & 0.000 & 0.000 & 0.746 & 0.000 \\
\hline Sum & -1.269 & -0.056 & -0.157 & -1.010 & -0.387 & -0.247 \\
\hline Sum Sq. Dev. & 251.686 & 252.045 & 251.919 & 252.644 & 119.849 & 105.938 \\
\hline Observations & 254 & 254 & 254 & 254 & 121 & 107 \\
\hline
\end{tabular}

Appendix 5: Summary of Stationarity (Unit Root) Test Results 


\begin{tabular}{|c|c|c|c|c|c|c|c|c|c|}
\hline Variables & & $\begin{array}{c}\text { Levin \& } \\
\text { Chin }\end{array}$ & Pvalue & $\begin{array}{l}\text { Pesran } \\
\text { \&Shin }\end{array}$ & Pvalue & $\begin{array}{l}\text { ADF } \\
\text { Fisher }\end{array}$ & Pvalue & $\begin{array}{c}\text { Philip } \\
\text { Peron \& } \\
\text { Fisher } \\
\end{array}$ & Pvalue \\
\hline \multirow{2}{*}{ BS } & level & $-4.564 *$ & 0 & $--3.389 *$ & 0 & $94.54 *$ & 0.001 & $180.72 *$ & 0 \\
\hline & $1^{\text {st }}$ diff. & - & - & - & - & - & - & - & - \\
\hline \multirow[b]{2}{*}{ BI } & level & $-3.566^{*}$ & 0 & $-3.346^{*}$ & 0 & 97.977* & 0.001 & $216.69 *$ & 0 \\
\hline & $1^{\text {st }}$ diff. & - & - & - & - & - & - & - & - \\
\hline \multirow{2}{*}{$\log$ GDP } & level & -3.819 & 0.999 & 8.508 & 1 & 1.783 & 1 & 0.037 & 1 \\
\hline & $1^{\text {st }}$ diff. & $16.434 *$ & 0 & $-7.065^{*}$ & 0 & $156.108^{*}$ & 0 & 88.773* & 0 \\
\hline \multirow{2}{*}{ logOpenness } & level & -0.966 & 0.1595 & -0.259 & 0.602 & 34.886 & 0.98 & $184.24 *$ & 0 \\
\hline & $1^{\text {st }}$ diff. & $-6.379 *$ & 0 & $-6.3794 *$ & 0 & $143.581^{*}$ & 0 & 666.034* & 0 \\
\hline \multirow{2}{*}{ A VGEXP } & level & $-8.360 *$ & 0 & $-6.056^{*}$ & 0 & $121.492 *$ & 0 & 218.204* & 0 \\
\hline & $1^{\text {st }}$ diff. & - & - & - & - & - & - & - & - \\
\hline \multirow{2}{*}{ CEODual } & level & $-3.066^{*}$ & 0.001 & $-2.705^{*}$ & 0 & $27.49 *$ & 0.001 & $52.23 *$ & 0 \\
\hline & $1^{\text {st }}$ diff. & - & - & - & - & - & - & - & - \\
\hline \multirow{2}{*}{ DMBA } & level & $-6.622 *$ & 0 & $-5.113^{*}$ & 0 & 116.93* & 0 & $246.36^{*}$ & 0 \\
\hline & $1^{\text {st }}$ diff. & - & - & - & - & - & - & - & - \\
\hline \multirow{2}{*}{ ER } & level & $-3.689^{*}$ & 0 & $-3.529 *$ & 0 & $100.84 *$ & 0 & $218.22 *$ & 0 \\
\hline & $1^{\text {st }}$ diff. & - & - & - & - & - & - & - & - \\
\hline \multirow{2}{*}{ LEV } & level & $-83.707 *$ & 0 & $-14.507 *$ & 0 & $90.33^{*}$ & 0.001 & $105.22 *$ & 0 \\
\hline & $1^{\text {st }}$ diff. & - & - & - & - & - & - & - & - \\
\hline \multirow{2}{*}{ FS } & level & $-90.289^{*}$ & 0 & -17.34 & 0 & $68.73 *$ & 0.085 & $105.86^{*}$ & 0 \\
\hline & $1^{\text {st }}$ diff. & - & - & - & - & - & - & - & - \\
\hline \multirow{2}{*}{ Tobin's q } & level & $-4.755^{*}$ & 0 & $-2.112 *$ & 0.0174 & $74.12 *$ & 0.036 & 115.34* & 0 \\
\hline & $1^{\text {st }}$ diff. & - & - & - & - & - & - & - & - \\
\hline \multirow{2}{*}{ NPM } & level & 5.367 & 1 & -1.489 & 0.068 & 68.32 & 0.091 & $117.24 *$ & 0 \\
\hline & $1^{\text {st }}$ diff. & $7.879 *$ & 0 & $-6.167 *$ & 0 & 141.93* & 0 & $283.26^{*}$ & 0 \\
\hline \multirow{2}{*}{ ROA } & level & $-55.587^{*}$ & 0 & -9.395 & 0 & 87.993* & 0.002 & 153.611* & 0 \\
\hline & $1^{\text {st }}$ diff. & - & - & - & - & - & - & - & - \\
\hline \multirow{2}{*}{ BIXFM } & Level & $-8.231 *$ & 0 & $-5.315^{*}$ & 0 & $-119.89^{*}$ & 0 & $236.58^{*}$ & 0 \\
\hline & $1^{\text {st }}$ diff & - & - & - & - & - & - & - & - \\
\hline \multirow{2}{*}{ BIXETHC } & Level & $-8.231 *$ & 0 & $-5.315^{*}$ & 0 & $-119.89^{*}$ & 0 & $236.58 *$ & 0 \\
\hline & $1^{\text {st }}$ diff & - & - & - & - & - & - & - & - \\
\hline \multirow{2}{*}{ BIXMBA } & Level & $-8.231 *$ & 0 & $-5.315^{*}$ & 0 & $-119.89 *$ & 0 & $236.58^{*}$ & 0 \\
\hline & $1^{\text {st }}$ diff & - & - & - & - & - & - & - & - \\
\hline
\end{tabular}

Note: $\mathrm{p}$ values for Fisher tests are based on the Asymptotic Chi-square Distribution, hence others assume asymptotic normality. *significant at $5 \%$ level.

\begin{tabular}{lrrrr}
\hline \multicolumn{4}{c}{ Appendix 6: Co-integration test of the estimated regression equation-test serial correlation of the residuals } \\
\hline Variable & Coefficient & Std. Error & t-Statistic & Prob. \\
\hline C & 10.666 & 1.204 & 8.857 & 0.000 \\
RESID01(-1) & 0.018 & 0.011 & 1.595 & 0.011 \\
\hline
\end{tabular}

Effects Specification

Cross-section fixed (dummy variables)

Weighted Statistics

\begin{tabular}{lccr}
\hline R-squared & 0.734 & Mean dependent var. & 43.792 \\
Adjusted R-squared & 0.706 & S.D. dependent var. & 241.061 \\
S.E. of regression & 132.191 & Sum squared resid. & 4019107. \\
F-statistic & 26.432 & Durbin-Watson stat & 1.477 \\
Prob.(F-statistic) & 0.000 & & \\
& \multicolumn{1}{c}{ Unweighted Statistics } \\
\hline R-squared & 0.456 & Mean dependent var. & 10.699 \\
Sum squared resid. & 4023361 & Durbin-Watson stat & 1.632 \\
\hline
\end{tabular}

